\title{
Late highstand patterns of shifting and stepping coastal barriers and washover-fans (late Messinian, Sorbas Basin, SE Spain)
}

\author{
Th.B. Roep ${ }^{\mathrm{a}, 1}$, C.J. Dabrio ${ }^{\text {b.2 }}$, A.R. Fortuin ${ }^{\mathrm{a},{ }^{*}, \text { M.D. Polo }}{ }^{\mathrm{b}}$ \\ "Department of Sedimentan Geology; Faculty of Earth Sciences, Vrije Universiteit, De Boelelaan 1085, \\ I081 HV Amsterdam. The Netherlands \\ ${ }^{b}$ Dpto. de Estratigrafía and Instihuto de Geología Económica-CSIC. Universidad Complatense, 28040-Madrid, Spain
}

Received 23 December 1996: accepted 23 September 1997

\begin{abstract}
The late Messinian Sorbas Member, up to $75 \mathrm{~m}$ thick, consists in its type area of a parasequence set of three prograding coastal barriers (sequences I-III), associated with lagoon and washover sediments. Around the town of Sorbas these strata can be studied exceptionally well due to absence of burrowing by raised Messinian salinities and exposure along a network of up to $30 \mathrm{~m}$ deep canyons. Fifteen vertical sections were logged and carefully correlated. This permits to reconstruct and discuss patterns of relative sea-level movements between decimetres, up to $15 \mathrm{~m}$ within a parasequence. Excellent examples of non-tidal transgressive facies are characterized by lagoon and washover sediments instead of the usual combination of washover and tidal deposits (channel and flood-tidal delta). Implications for the sandstone connectivity are given. The lower two sequences are deposited in a relatively large, tectonically enhanced wedge-shaped accommodation space. They show both fining-up, deepening sequences, followed by prograding coarsening-up shoaling sequences and can be compared to the classical parasequences of the Western Interior Basin (USA). Progradation of sequence II was interrupted by a major slide event (most likely triggered by an earthquake), which caused more than $400 \mathrm{~m}$ seaward slumping of a stretch of 1 $\mathrm{km}$ of coastal sands. The architecture of sequence III is more complex due to limited accommodation space characteristic for the late highstand, so that this setting was very sensitive to sea-level fluctuations. This resulted in an intricate pattern of juxtaposed and superposed lagoonal muds, washover fans and swash zones. So-called 'stranded' coastal barriers occur, which were left behind after seaward jump of the coastline over more than $1.5 \mathrm{~km}$ during forced regression. The pattern of reconstructed sea-level positions is well comparable to the sequential pattern shown by the correlated equivalents along the northern basin margin, which belong to the so-called Terminal Carbonate Complex. The problem of ranking the complex sequence III as one or more prarasequences and its consequences for cyclostratigraphy are shortly discussed. Two models of washover formation are given, respectively during more rapid and more slow sea-level rise. The influence of synsedimentary folding on the location of barriers is discussed and also the source area of extra- and intraclasts supplied to barriers and washovers. After deposition of the Sorbas Member the sea withdrew from the Sorbas Basin, probably as a result of the major downdrop in the Mediterranean at the maximum isolation during the Salinity Crisis. It is suggested that the semi-enclosed setting of the basin resulted only in limited, localized erosion, in contrast to the deeper adjacent Vera Basin, which was more open to the Mediterranean.
\end{abstract}

Keywords: Messinian; sea-level fluctuations; beach barriers; washover fan; sequence stratigraphy

\footnotetext{
* Corresponding author. E-mail: fora@geo.vu.nl

1 Th.B. Roep deceased 15 September 1997.

2 E-mail: Dabrio@eucmax.sim.ucm.es
} 


\section{Introduction}

Sedimentary bodies deposited in coastal settings reflect a highly variable architecture, which is mainly governed by factors as sediment supply, wave- and tidal processes, coastal morphology and accommodation space. Seaward, these coastal sedimentary units interfinger with muddy shelf deposits, but landward these either end abruptly, or show rapid facies changes to tidal, lagoonal, washover-fan and fluviatile deposits. With time the pattern becomes more complicated as the above-mentioned factors change, especially when landward erosional surfaces start to play a prominent role as soon as a position above base-level is reached.

Apart from presently well known possibilities to discriminate the vertical upward and downward relative movements of sea-level within sequences of coastal deposits, a more complicated effort is to incorporate the three-dimensional evolution of the shoreline. Another complexity is the determination of the timeframe in which the distinguished patterns of coastal sequences have been formed. Generally, coastal deposits do not easily lend themselves for precise dating of successive depositional steps. Recent and subrecent deposits form an exception, e.g. through $\mathrm{C}-14$ dating possibilities. Although sequence stratigraphy helps to distinguish related sediment packets deposited under conditions of varying accommodation space, careful sedimentological analysis should precede a sequence stratigraphic scheme (Van Wagoner and Bertram. 1995). Even then it is good to keep in mind that the number of variations on the general sequence stratigraphic model is limited only by the imagination (Posamentier and Allen, 1993).

The late Messinian Sorbas Member and its lateral equivalent at the basin margin (TCC) in southern Spain offers an excellent example of coastal deposits laid down in a tectonically active basin margin that was strongly affected by sea-level fluctuations of various orders (Roep et al., 1979; Dabrio and Polo, 1995; Goldstein and Franseen, 1995; Martín and Braga, 1996). Dabrio and Polo (1995) connected these with third-, fourth- and fifth-order cycles sensu Vail et al. (1977). Also should be thought of cyclicity forced by precession (and/or obliquity), given the strong cyclicity of the underlying Messinian marine marls and gypsum (Krijgsman et al., 1995; Hilgen et al., 1995; Sierro et al., 1996) and evidence presented for late Messinian precessional parasequence stacking in Italian successions (Lickorish and Butler, 1996). For the Sorbas sequences this aspect is presently under investigation.

The anatomy and dynamics of the coastal barriers can be best studied around the town of Sorbas, thanks to the unique presence of up to $30 \mathrm{~m}$ deep river canyons which are oriented more or liess perpendicular to each other. These coastal deposits can be better studied here than in many other basins because of the following factors: burrowing is almost absent due to raised salinities (Roep et al., 1979): a three-dimensional insight is possible due to good exposure along variously oriented canyon walls; early diagenesis at tops of sequences (beach-rock formation; stromatolites) led to better preservation of the shallowest deposited strata; deposition in a protected embayment of the Messinian Mediterrarean, practically without tides and under climate-controlled sea-level fluctuations. Considering this excellent preservation, the purpose of this paper is to describe and discuss the development of the Sorbas coastal deposits as a function of available accommodation space, slope gradient and position of the basin margin under sealevel changes of diverse magnitudes. In addition, the enigmatic aspect of where to look within the Messinian stratigraphic record of the Sorbas Basin for the major sequence boundary formed when the sea-level of the Mediterranean dropped kilometres down, will be discussed briefly.

\section{Geological setting}

Late Cenozoic sedimentation in the eastern Betic Cordillera in SE Spain (Fig. 1) took place in partly interconnected intramontane pull-apart basins, shaped by the ongoing approach of the African and European plates. Both the substratum of the basins and the adjacent mountain ranges is made up of metamorphic and metasedimentary rocks belonging to the Internal Zone of the Betic Cordillera (Fig. 1). The Sorbas Basin is delimited by the Sierra de los Filabres to the north and the Sienra Alhamilla and Sierra Cabrera to the south (Fig. 1). Many textural and compositional properties of the Late Miocene basin fill are inherited from these adjacent highs, 


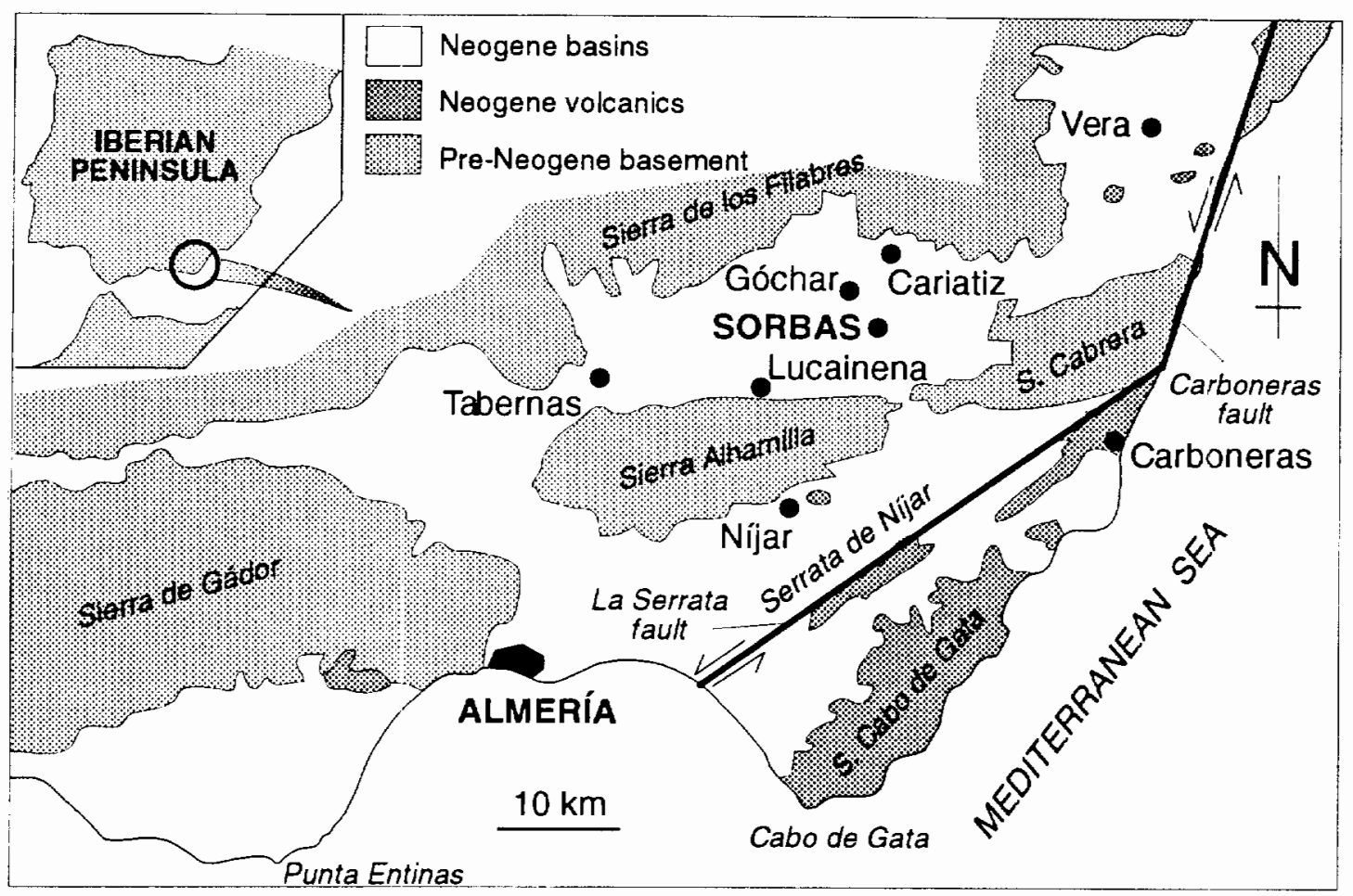

Fig. 1. Tectonic sketch map of the Sorbas Basin and surrounding areas, indicating localities cited in the text.

especially from the Filabres massif, which supplied most of the detritus.

In the Sorbas Basin strike-slip deformation was mainly active in late Tortonian time (Montenat et al., 1987; Biermann, 1995; Stapel et al., 1996), causing folding, uplift and a northward shift of the southern basin margin (Ott d'Estevou, 1980; Montenat and Ott d'Estevou, 1996). During Messinian times the important $\mathrm{N}-\mathrm{S}$-trending sinistral Palomares fault (Fig. 1) was active, which is located some $25 \mathrm{~km}$ east of Sorbas, causing displacements in the order of 25 km (Völk, 1967; Montenat et al., 1987; Biermann, 1995). This fault system is intersected by the NESW-oriented Serrata fault zone, which was active during various episodes from the Middle Miocene onwards in the adjoining Nijar Basin (Montenat et al., 1987; Boorsma, 1993; Biermann, 1995).

Sediments filling the Sorbas Basin range in age from Middle Miocene to Quaternary (Fig. 2). After the late Tortonian phase of transpressional deformation the Messinian Turre Formation (Völk and Rondeel, 1964) was deposited, which includes three members: a basal onlapping shallow-marine calcarenite unit (Azagador Member), overlain by open marine marlstones (Abad Member) of early Messinian age (Ruegg, 1964; Dronkert and Pagnier, 1977; Troelstra et al., 1980; Weijermars et al., 1985; Van de Poel, 1994). At that time bioherms and fringing reefs (Canteras Member) settled along the basin margins. These deposits show complex mutual relationships (Martín and Braga, 1994; Fig. 2) and interfinger with Abad marls towards the centre of the basin. The overlying Caños Formation represents the deposits formed during the Messinian salinity crisis and is made up of three members, respectively called the Yesares, Sorbas, and Zorreras members (Fig. 2). The Yesares Member mainly consists of selenite gypsum which locally is over $120 \mathrm{~m}$ thick (Dronkert, 1977; Ott d'Estevou, 1980, Dronkert, 1985; Gautier et al., 1994). Following the fall of sea-level that favoured the subaqueous deposition of Yesares gypsum by evaporation, a less saline and onlapping succession was deposited, the Sorbas Member. 


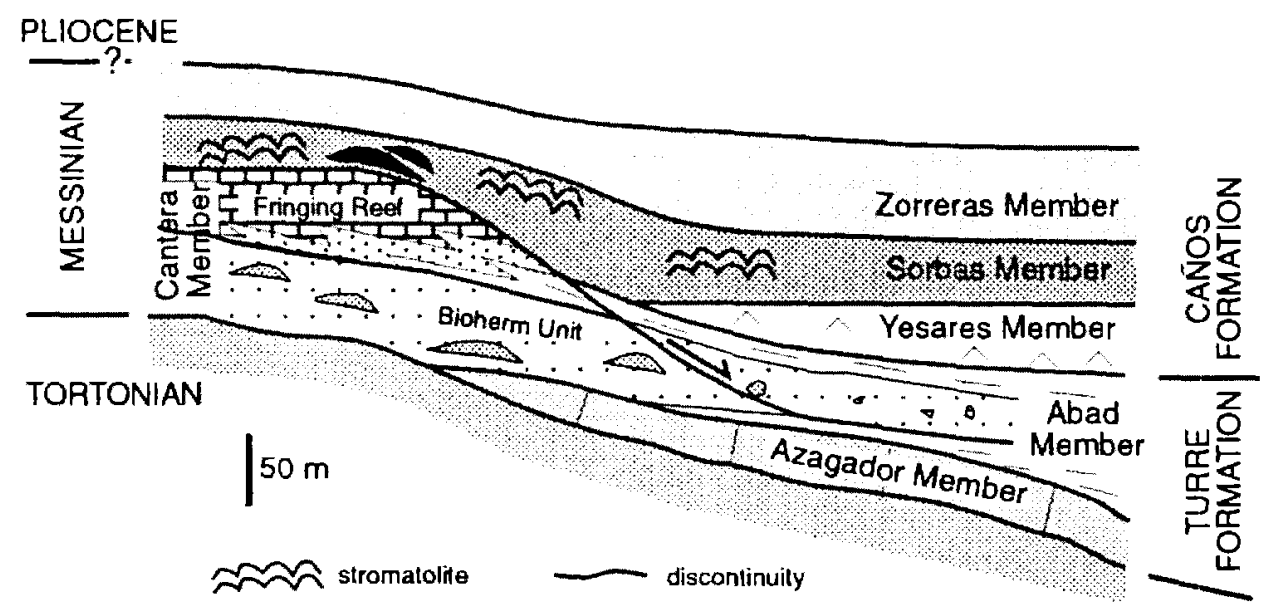

Fig. 2. Messinian stratigraphic framework for the Sorbas Basin (modified after Martín and Braga, 1994), using the lithostratigraphic units introduced by Ruegg (1964), Völk and Rondeel (1964) and Dronkert and Pagnier (1977).

During deposition of the Sorbas Member the Sorbas Basin was a narrow embayment open to the east (Fig. 3) and possibly also to the southeast because uplift of the Sierra Cabrera mainly occurred later. The member is up to $70 \mathrm{~m}$ thick and consists of three superposed coastal sandstone bodies (sequences IIII, Figs. 4-6), separated by shelf muds. Each depositional sequence shows upward coarsening and shallowing and eastward progradation. Finely laminated clays and marls occur at the base representing the offshore facies. Upward, micaceous sands, sandy calcarenites and conglomerates follow, indicative of an offlapping beach-barrier environment (Roep et al., 1979). Coastal sands and calcarenites with local algal mats (stromatolites) dominate in the western, more landward areas, whereas offshore muds predominate towards the eastern parts of the basin.

The Sorbas Member overlies evaporites in the centre of the basin, or collapse breccias of dissolved marginal edges of the latter sediment. In marginal areas it also may onlap the reef cores and their clinoforms. Then oolitic lirnestones (representing shallow-marine bars) and algal mats predominate and this facies association is known as the Terminal Carbonate Complex (TCC, Esteban and Giner, 1977; Esteban, 1979). This TCC also includes Porites patch-reefs and thrombolites and in places like Góchar (Fig. 1), these add to conglomeratic and fine-grained siliciclastics (Dabrio et al., 1985b; Martín et al., 1993; Dabrio and Polo, 1995) that can be seen to onlap the topographical heights of the older fringing reefs during a second time of normal to slightly more saline sea water influxes after the deposition of the Yesares Member (Martín et al., 1993). The lateral relation between the Sorbas Member and the TCC was certified by Dabrio and Polo (1995), who correlated typical sections of both units, using lithology, sequential patterns and stromatolite layers. The TCC has been widely studied in the Mediterranean in relation with reef growth (Esteban, 1979; Dabrio et al., 1981; Martín and Braga, 1994) and the Messinian salinity crisis (Martín et al., 1993; Van de Poel, 1994).

After deposition of the Sorbas Member and its lateral TCC equivalents, deposition of the terrestrial Zorreras Member followed. This unit of red mudstones, sandstones and conglomerates is up to 60 $m$ thick and shows an upward- and westward-coarsening trend. The member typically includes two interbeds of white lagoonal limestone containing a so-called caspibrackish Lago Mare fauna (Hydrobia, ostracods and small shells) indicating a latest Messinian age (Roep and Beets, 1977; Roep and Van Harten, 1979; Ott d'Estevou, 1980; Van de Poel, 1994). This characteristic biofacies is widespread in the entire Mediterranean province (Cita et al., 1990). The Zorreras Member ends with 2-3 m of yellow, fossiliferous Pliocene sands and conglomerates and is followed by reddish Plio-Pleistocene fluviatile conglomerates (Góchar Formation). 


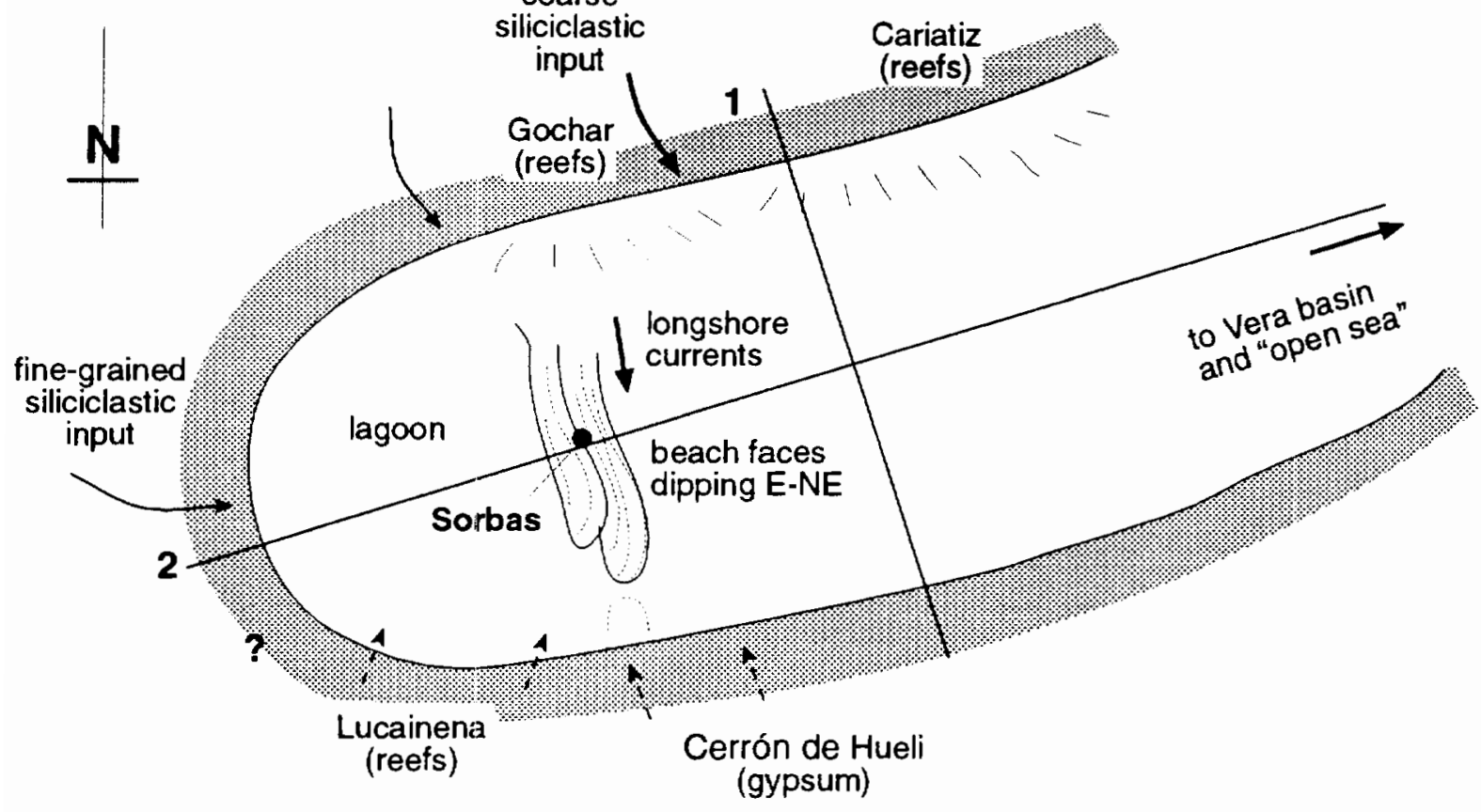

NNW - SSE

1 Gochar-Cariatiz

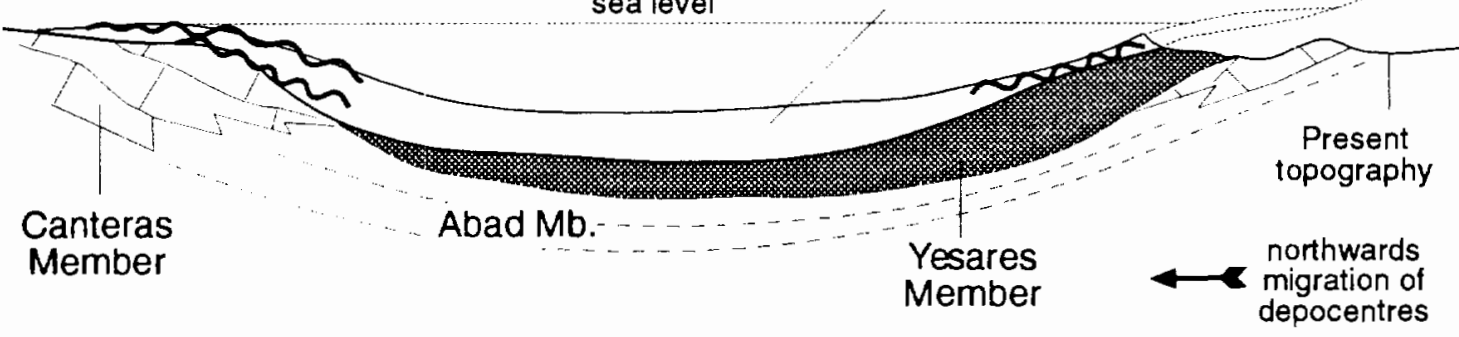

$W-E$

\section{2}

\section{Sorbas}

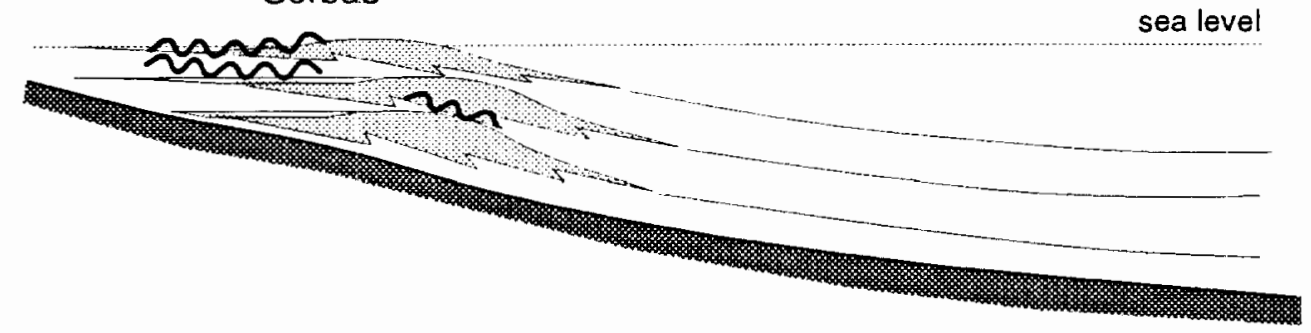

Fig. 3. Simplified palaeogeography and schematic representative cross-sections of the late Messinian Sorbas Basin, with the main stratigraphic units cited in the text. (Modised from Dabrio and Polo, 1995.) Note that post-depositional compaction and flexure of the basin accentuates the apparent dip of units and shape of the basin. 

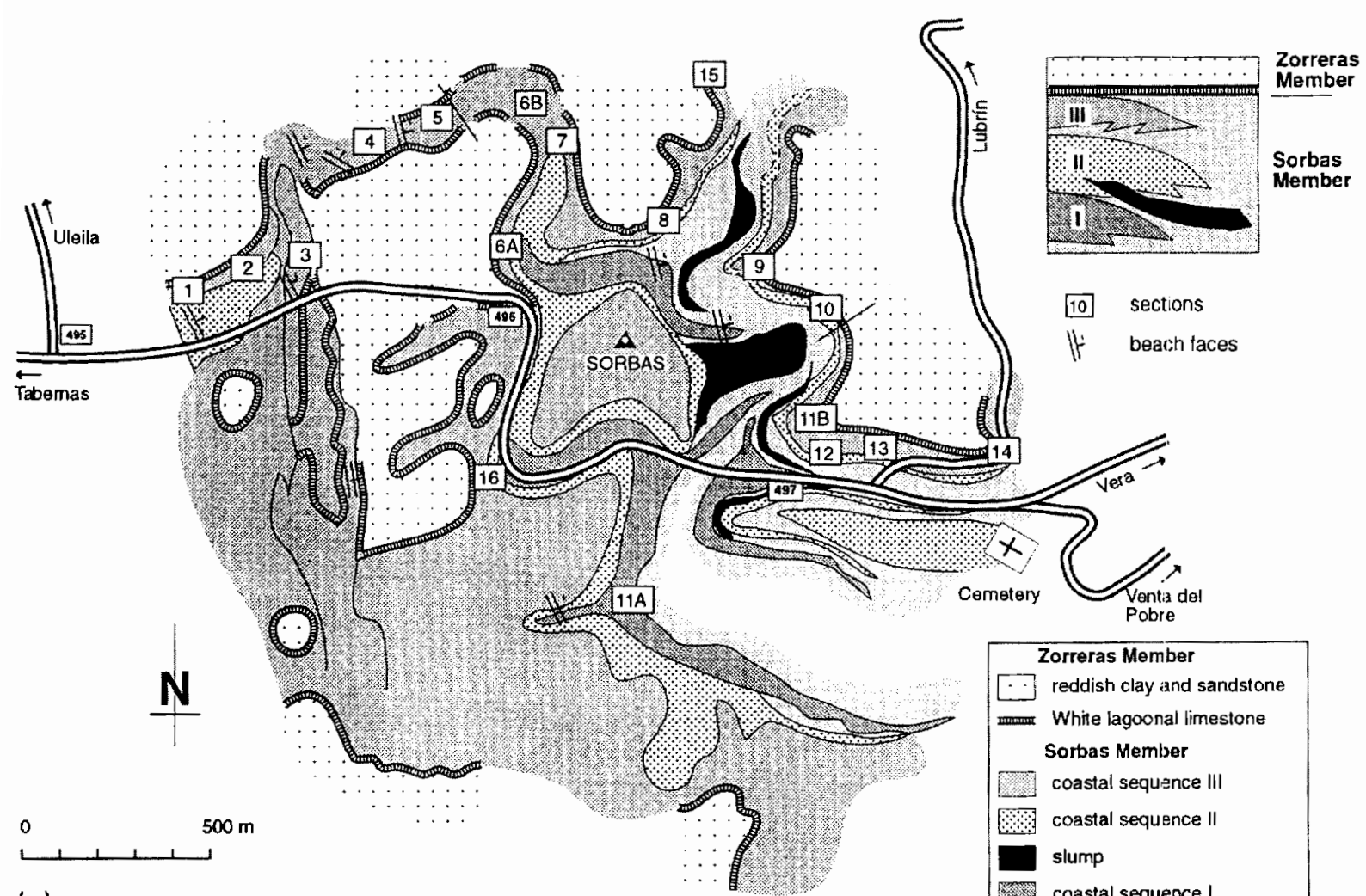

\begin{tabular}{|l}
\hline Zorreras Member \\
$\square$ reddish clay and sandstone \\
White lagoonal limestone \\
Sorbas Member \\
coastal sequence III \\
coastal sequence II \\
slump \\
coastal sequence I \\
shelf to basin sediments
\end{tabular}

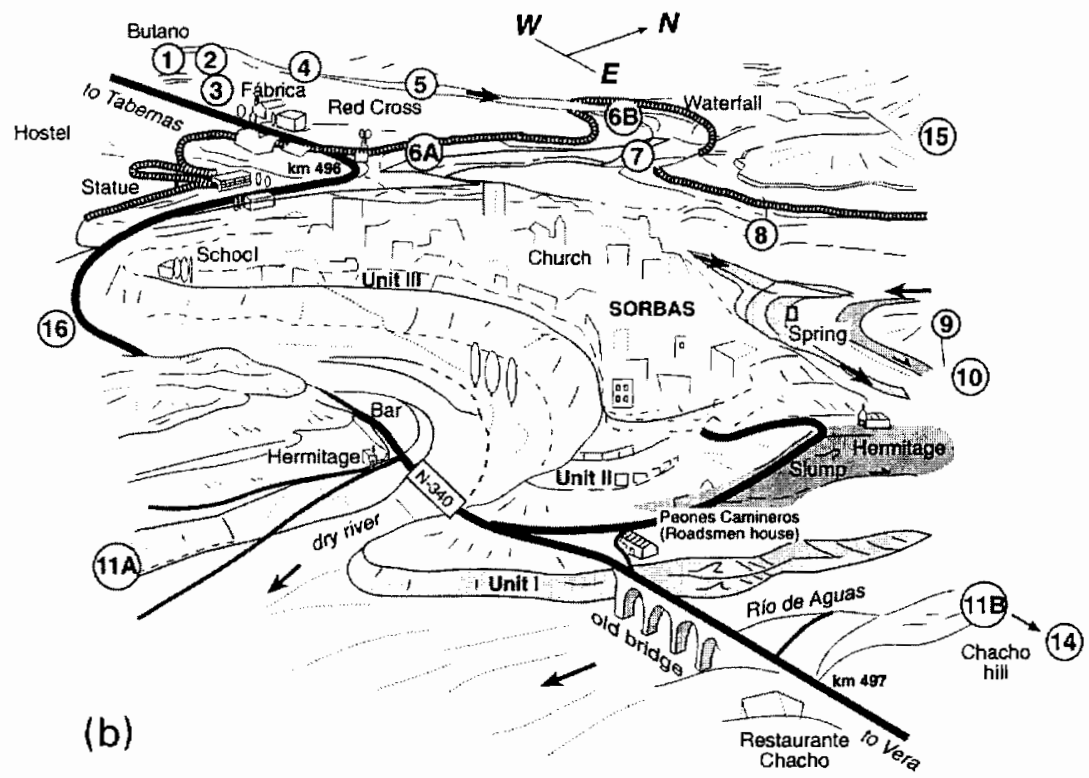

Fig. 4. Maps of the Sorbas study area. (a) Geological map, showing the distribution of the coastal sequences I--III and the localities of the sections discussed. (b) Panoramic view, looking towards the west (drawn after oblique air-photo), showing the particular canyon morphology and location of sequences I-III. 


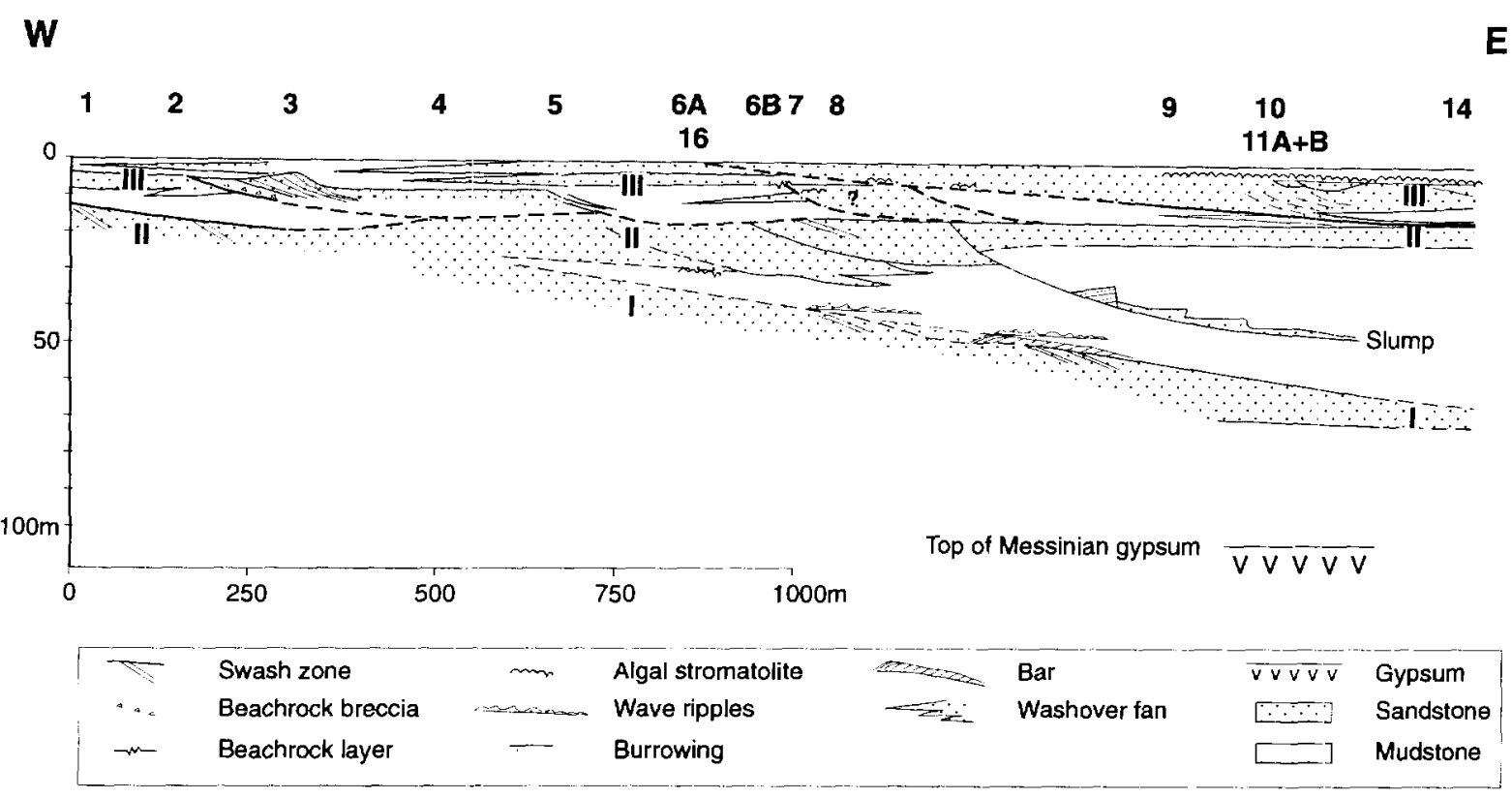

Fig. 5. Generalised W-E facies diagram of the Sorbas Member, indicating the position of the sections outlined in Fig. 4.

\section{Methods of study and presentation of data}

In order to obtain a maximum insight in the facies geometry, all exposures in the canyon walls around Sorbas and along the roads were first sketched, carefully measured and mapped (Fig. 4a). Altogether fifteen sections were logged (Fig. 4a). Lateral tracing along the cliffs of individual units and projection of sections along the depositional strike enabled us to prepare a schematic facies diagram (Fig. 5), which is based on the lithologically correlated numbered sections (Fig. 6).

This paper is organised in such a way that first a general outline and discussion of the logged sections are presented. Next follow paragraphs concentrating on the transgressive units of sequences II and III, which demonstrate best the nature of the transgressions and progradations and patterns related to smaller sea-level fluctuations. The paper then continues with a discussion concerning the location and development of barrier islands and lagoons in the basin, sequence stratigraphic aspects and relations with the Terminal Carbonate Complex.

\section{Introduction to the Sorbas coastal parasequences}

Essentially, the Sorbas Member constitutes a stack of three parasequences (sensu Van Wagoner and Bertram, 1995), arranged in an up-stepping and basinward-stepping pattern. Coastal progradation occurred more gradually and regularly during the first two sequences. This resulted in classical coarsening-up sequences with shelf mud at the bottom and calcarenites at the top, often showing gently seaward-inclined swash lamination. In contrast, the third sequence displays a much more complex facies pattern, due to extensive presence of washover-fan sands and lagoonal muds in back-barrier settings. This is interpreted as the result of more abrupt shifts of the coastline under conditions of a more restricted accommodation space than the previous sequences. The pattern of three stacked parasequences occurring just before the late Messinian downdrop event (discussed in Section 11) suggests that these can best be attributed to a late highstand sequence set. For a detailed account of the sedimentological aspects of the Sorbas Member the reader is referred to papers by Roep and Beets (1977) and Roep et al. (1979). 


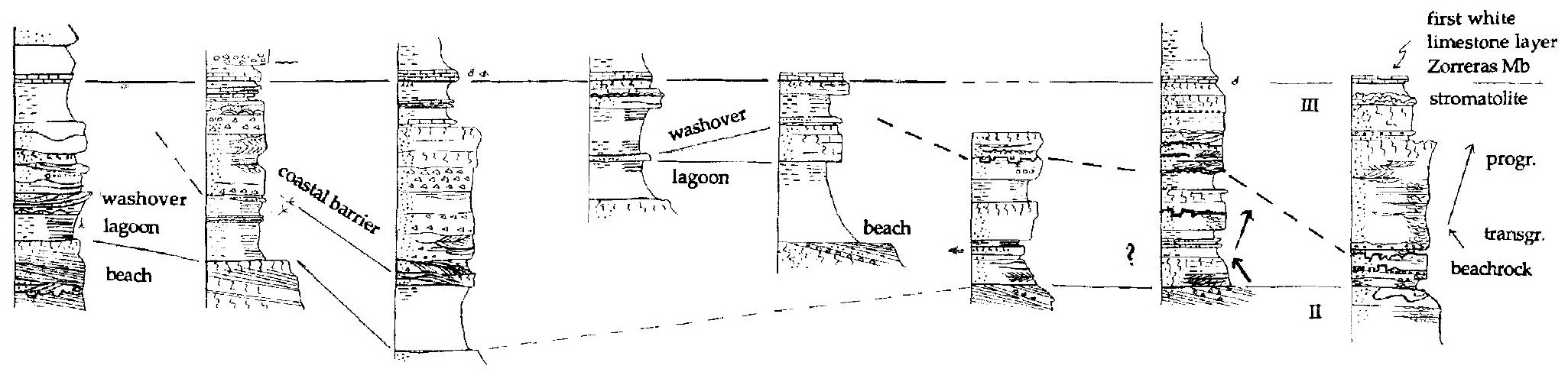

$6 \mathrm{~A}$

8

9

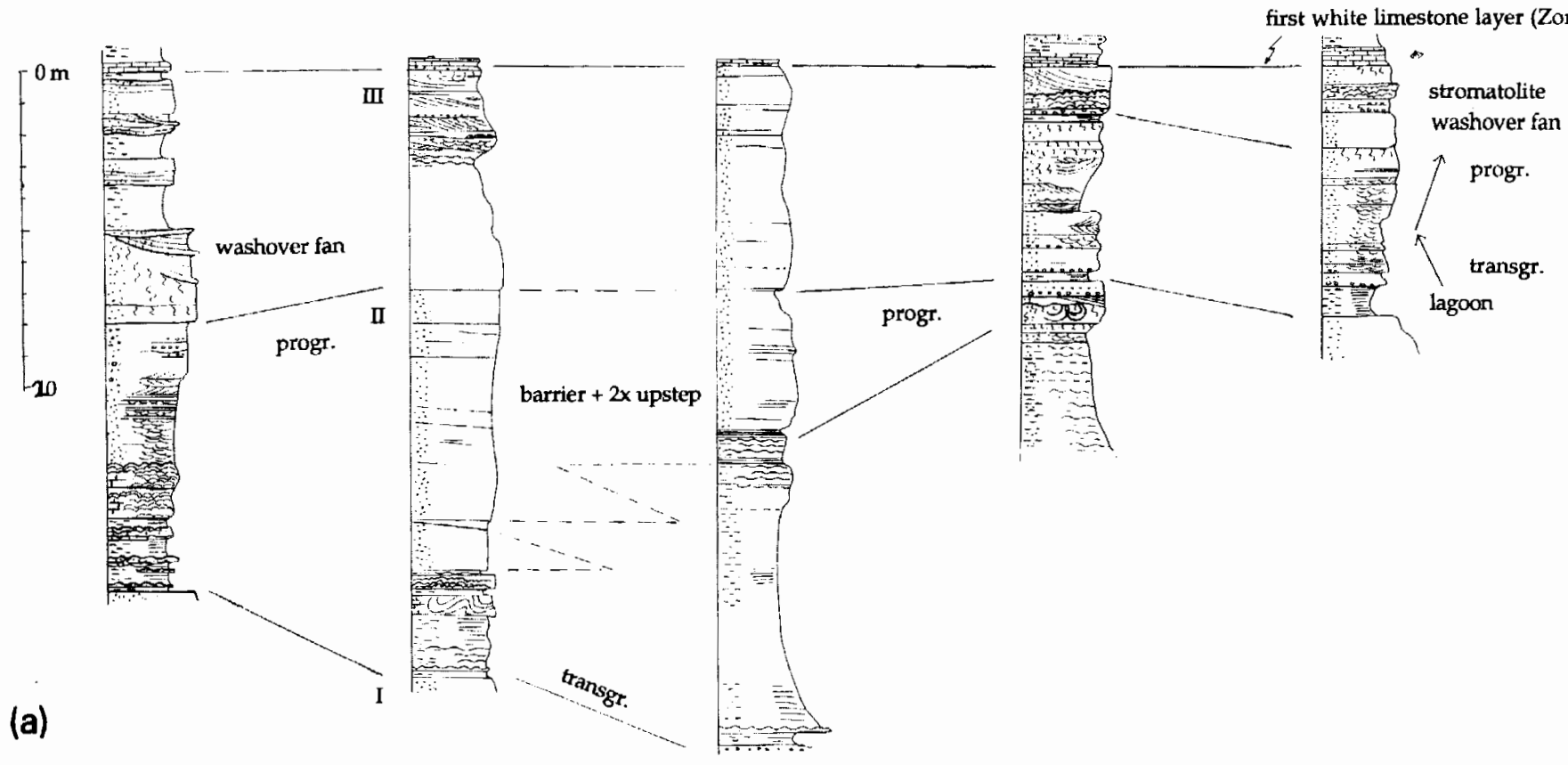

Fig. 6. Corrclated sediment logs of the sections around Sorbas. For location, see Fig. 4. 

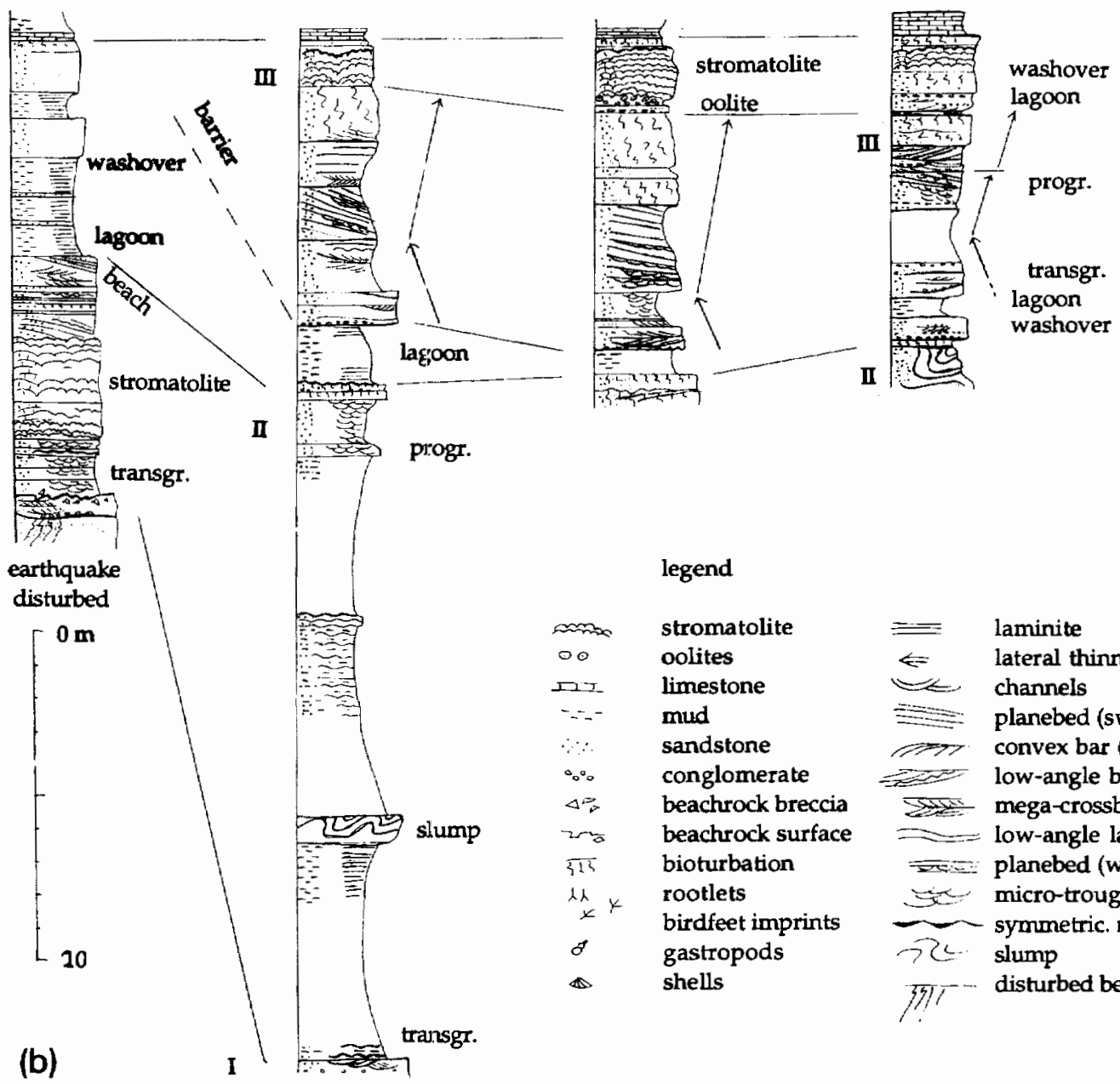

Fig. 6 (continued).

The stratigraphic cross-section (Fig. 5) presents a schematic overview of the most important lateral changes within the parasequences. It is based on the fifteen logged sections (Fig. 4a, Fig. 6), using the base of the first (lowermost) of the two white lagoonal limestone beds of the Zorreras Member as horizontal reference line. This 0.5 to $1 \mathrm{~m}$ thick, basin-wide occurring 'Lago Mare' bed is interpreted as an isochronous, almost horizontally deposited surface. Around Sorbas it rests directly on top of the calcarenites and sandstones of the Sorbas Member, but further east, in the basin centre. up to $15 \mathrm{~m}$ of pink and brown coloured muds and sandstones of the Zorreras Member appear below the first white lagoonal limestone layer separating it from the top of Sorbas Member. Relative to this reference line, the top of the prograding sandy calcarenite sequence I differentially subsided $27 \mathrm{~m}$ over a distance of $\sim 1 \mathrm{~km}$, measured at right angles to the shoreline (towards the east) between sections 5 and 10 .

Most subsidence (and/or compaction) must have taken place before deposition of prograding coastal sequence II, because this unit only shows a differential subsidence of $8 \mathrm{~m}$ to the east, between sections 
8 and 10. The wedge-shaped accommodation space was filled up by offshore to coastal sediments with a symmetrical facies trend consisting of a lower fining-upward part (deepening, transgressive sequence) and an upper coarsening-upward part (shallowing, prograding sequence).

Renewed sea-level rise after unit II produced a more box-shaped accommodation space for deposition of unit III. This means that the accommodation space available for deposition of units II and III had a different geometry, determining a different facies distribution. Unit III furthermore provides fine examples of seaward-stepping and landward-stepping coastlines as well as progradation in the deeper eastern part.

Parasequence I. During its deposition the coastline prograded over at least $1 \mathrm{~km}$, measured at right angles to the preserved swash zones depositing a lithosome of coastal sandstone, informally referred to as sandy calcarenite unit I. Synsedimentary faults, liquefaction phenomena and meter-scale convolutions indicate tectonic instability during deposition. This unit will not be discussed in more detail.

Parasequence II. Due to eastward tilting and prior to renewed transgression a wedge-shaped accommodation space formed and the sequence starts with a spectacularly well preserved flooding surface. It is followed by a wedge of offshore mudstone, coarsening upward in prograding sandy calcarenites. Progradation of these geometrically complex calcarenites took place over at least $1.5 \mathrm{~km}$. Observed variations in thickness of these strata, formed above normal wave base, allow to deduce variations of sea-level of a scale of decimetres to $15 \mathrm{~m}$. A relative sealevel rise can be deduced from the stacking of swash zones and seaward stepping-up of the sandy calcarenite sequence over shelf muds. Liquefaction and slumping moved sand from the coastal zone to the shelf, probably as a result of earthquakes.

Parasequence III. During initial transgression landward up-stepping washover fans were formed, which interfingered with lagoonal muds. With ongoing transgression, ravinement surfaces affected these washover fans. This induced the formation of an erosively overlying barrier with an active swash zone facing the sea to the east. Subsequent sea-level drop forced the coastline to jump seaward. This process is shown by steepening-up and lateral fining of the swash lamination and lateral increase in the amount of burrowing and draping by stromatolites. After this sea-level fall, renewed transgression again moved a girdle of washover fans landward, filling the available accommodation space, overstepping the previous barrier. Finally, progradation occurred in the most seaward part of the complex unit III, resulting in a third coarsening-up unit in the east.

At certain moments stromatolites draped the barrier island and lagoon, suggesting a temporary cessation of the siliciclastic input to the former shore. This seems to be related to inactivity and/or abandonment(?) of the barrier, perhaps caused by jumping to a new location. Stromatolites also have been found in an early transgressive setting overlying beachrock surfaces and erosional channels at the base of wave-rippled fining-up sequences.

\section{Sequence II}

\subsection{The transgressive part}

The finest example of the transgressive phase shows (section 8, Figs. 6 and 7 bottom) that the seaward dipping swash zone at the top of unit I is followed by a thin layer of lagoonal clay. A high bar, up to $2.1 \mathrm{~m}$, is overlying this lagoonal clay, but also interfingering with it. It increases in height in the landward direction (to SW) and shows intermittent growth. Each growth pulse shows a landward steepening of the foresets, sometimes with backflow ripples, developed in the wedge-shaped toesets extending into the lagoon. The latter ripples suggest strong landward currents. The toesets also contain bird-foot imprints produced during periods of low water after overwash. The bar is interpreted as a retrograding barrier under massive, but episodic overwash that stepped into a lagoon.

When the bar was overstepped by the transgressive sea, wave action in the foreshore locally eroded the gravelly beach-rock surface and carved up to 0.5 $m$ deep hollows in the top of the bar. A few blocks of beach rock remained behind on this ravinement surface. As transgression proceeded, the frequency and magnitude of overwash increased and transport of sediment to the back-barrier became massive, as the foreshore overstepped the barrier island. This effect is demonstrated by the change from high- to 
Concluding, the transgression after deposition of parasequence $I$ is interpreted to have been rapid considering the minor amount of erosion, the thin fining-upward transgressive sequence and the varied lithological expression below the prograding part of unit II.

\subsection{The prograding part}

The prograded part of sequence II, already described and interpreted by Roep et al. (1979) is only updated here. The muddy lower part is interpreted as offshore mud, deposited below normal wave base. The coarsening-up sandy and conglomeratic upper part (Fig. 8, lower column, interpreted as a coastal sequence above wave base) can be well compared to present-day coastal subenvironments in the Mediterranean (Fig. 8, upper part). From the deepest offshore muds and limestone intercallations upwards, the following is encountered within 10 to $15 \mathrm{~m}$ :

(1) Thin fine-grained, graded or very low-angle laminated storm beds alternating with mud (inferred original depth $15-40 \mathrm{~m}$ ). In the higher parts they are associated with thin swelling and thinning ripples with only low-angle laminations, formed by incipient orbital motion at the sea bottom without flow separation over the ripple crests.

(2) Symmetrical (pointed) wave ripples formed in fine, micaceous sand alternating with mud at an inferred original depth of $\sim 10-15 \mathrm{~m}$.

(3) Small-scale trough-shaped cross-bedded sandstone lacking a preferred orientation due to frequent wave activity above normal wave base (inferred depth less than $10 \mathrm{~m}$ ).

(4) Upwards, the wave-ripple cross-lamination shows wider troughs, associated with thickening-up
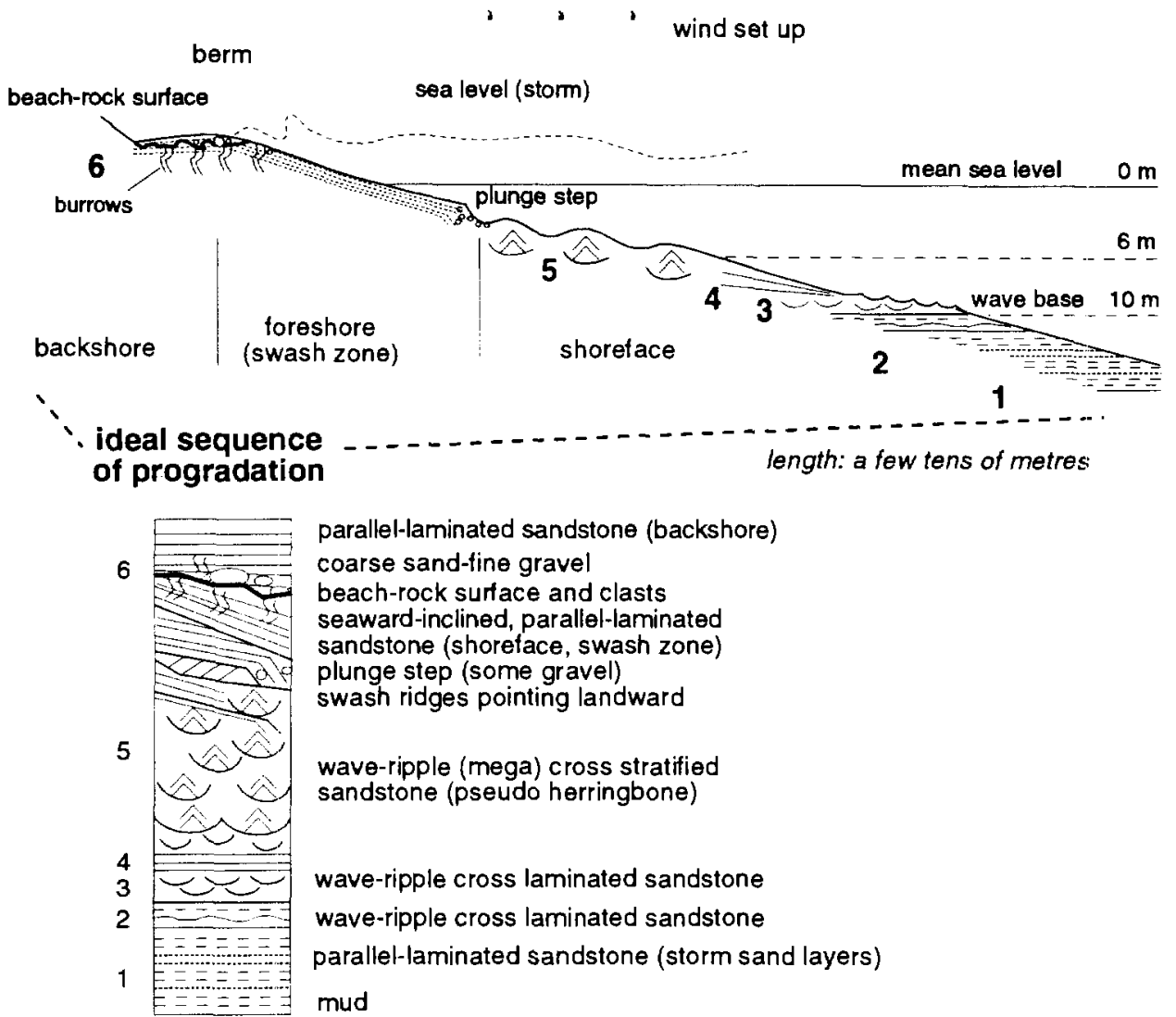

Fig. 8. Ideal facies succession in microtidal sandy beaches of Sorbas, compared to present-day coastal sub-environments in the western Mediterranean. 
intercalations of parallel laminated sand, due to episodic more intensive orbital motion which wiped out the wave ripples. The inferred depositional depth of the parallel-laminated sand ranged between 9 and $6 \mathrm{~m}$. The eastward palaeocurrent trend of occasional climbing ripples is normal, or slightly oblique to the shoreline, suggesting a seaward migration of the wave-generated ripples due to the return orbital movement of waves. Strong westerly winds, still common in this area, may have enhanced this pattern.

(5) Upward and landward, wave-generated trough-shaped mega-cross-bedding; interfingers with planar cross-bedding, indicating the seaward (to NE) growth of the plunge step at the base of the foreshore under the action of backswash. Coexistence of these two types of cross-bedding renders outcrops the appearance of herringbone cross-bedding, but the wave-related genesis is clear by the association with the swashzone. Furthermore wave ripples are associated with these features and never smallscale bidirectional current ripples (tidal linsen and flaser bedding). The deposits represent the lower part of the foreshore, where breaking waves accumulate the coarsest sediment available (Miller and Ziegler, 1968; Dabrio et al., 1985a). In low-energy coasts the breaker zone is characterised by a step at the base of the swash zone (Clifton et al., 1971; Davis et al., 1972) which probably marks the transition between upper and lower flow regimes (Tanner, 1968).

The seaward inclined parallel lamination curves downward to lesser dips at the lower, distal parts of the shoreface facies, and changes into planar cross-bedding directed offshore (set thickness 10 to $20 \mathrm{~cm}$ ). In fossil examples of sandy beaches the step is preserved as a change from parallel lamination (the common deposits of the foreshore swash zone) to tabular cross-bedding pointing to the open sea (Fig. 10; Dabrio et al., 1985a; Somoza et al., 1986-87).

Along tideless coasts, such as the present Mediterranean, the plunge step below the swashzone occurs between $0 \mathrm{~m}$ and $-1 \mathrm{~m}$ below mean sea-level (Dabrio, 1982). Therefore, the interfingering zone of low-angle seaward-dipping parallel lamination and seaward-oriented cross-bedding of the Sorbas Member is also interpreted to indicate this palaeodepth (Fig. 10). The maximum water depth of the wavegenerated megatrough-cross-bedding of unit 5 is estimated to have been $6 \mathrm{~m}$ at the most.
(6) Beach-rock breccia and burrowing structures. The inferred depositional depth is from current sealevel to $\sim 1-3 \mathrm{~m}$ above mean sea-level. At the top of the sequence intense burrowing occurs. This member represents foreshore and backshore sediments. Locally, calcareous breccias occur overlying an irregular erosional surface. According to Roep et al. (1979) these features are related to beach-rock erosion. Care must be taken not to mistake a beach-rock breccia for a beach-rock surface; the former may be washed into deeper levels and does not necessarily indicate the upper foreshore to berm zone of the beach face.

Concluding, these features, such as good roundness and high sorting of the grains, their occurrence in this particular vertical sequential pattern and overall geometry, are proper indicators of reflective coasts where the slope of the shelf is relatively steep and waves reach the coast almost undisturbed. Reflective beaches require low waves (less than 1 $\mathrm{m}$ high), and coarse sediment $(>0.6 \mathrm{~mm})$. Consequently they tend to occur in coasts sheltered or subjected to moderate to high energy (Short and Wright, 1983). Most of the sediment in reflective beaches accumulates in the upper foreshore generating high berms and beach cusps. The foreshore is rather steep (on average $2-5^{\circ}$ for beach units made up of coarse sand) with a plunge step in the lower part, where the coarsest sediment concentrates. Towards the sea the shoreface is less inclined, but relatively deep, without bars or other morphological features.

\subsection{Estimates of sea-level variations}

Careful correlation and study of the sections provides evidence for sea-level changes at $15 \mathrm{~m}$, metre and decimetre scales and examples will be discussed here. The mean thickness of the sandy and conglomeratic part ( $\sim 10 \mathrm{~m}$; Fig. 6$)$ is interpreted as the local normal wave base. Thicker intervals are therefore interpreted to be essentially the result of increased accommodation space related to a relative sea-level rise; similarly, thinner intervals reflect a sea-level drop. To facilitate description the successive sealevel positions have been numbered in Fig. 9 (1-5 for this sequence; $6-14$ for sequence III, discussed in the next section).

After tilting of sequence I relative sea-level rose $\sim 32 \mathrm{~m}$ from position 1 (Fig. 9) to position 2 at high- 

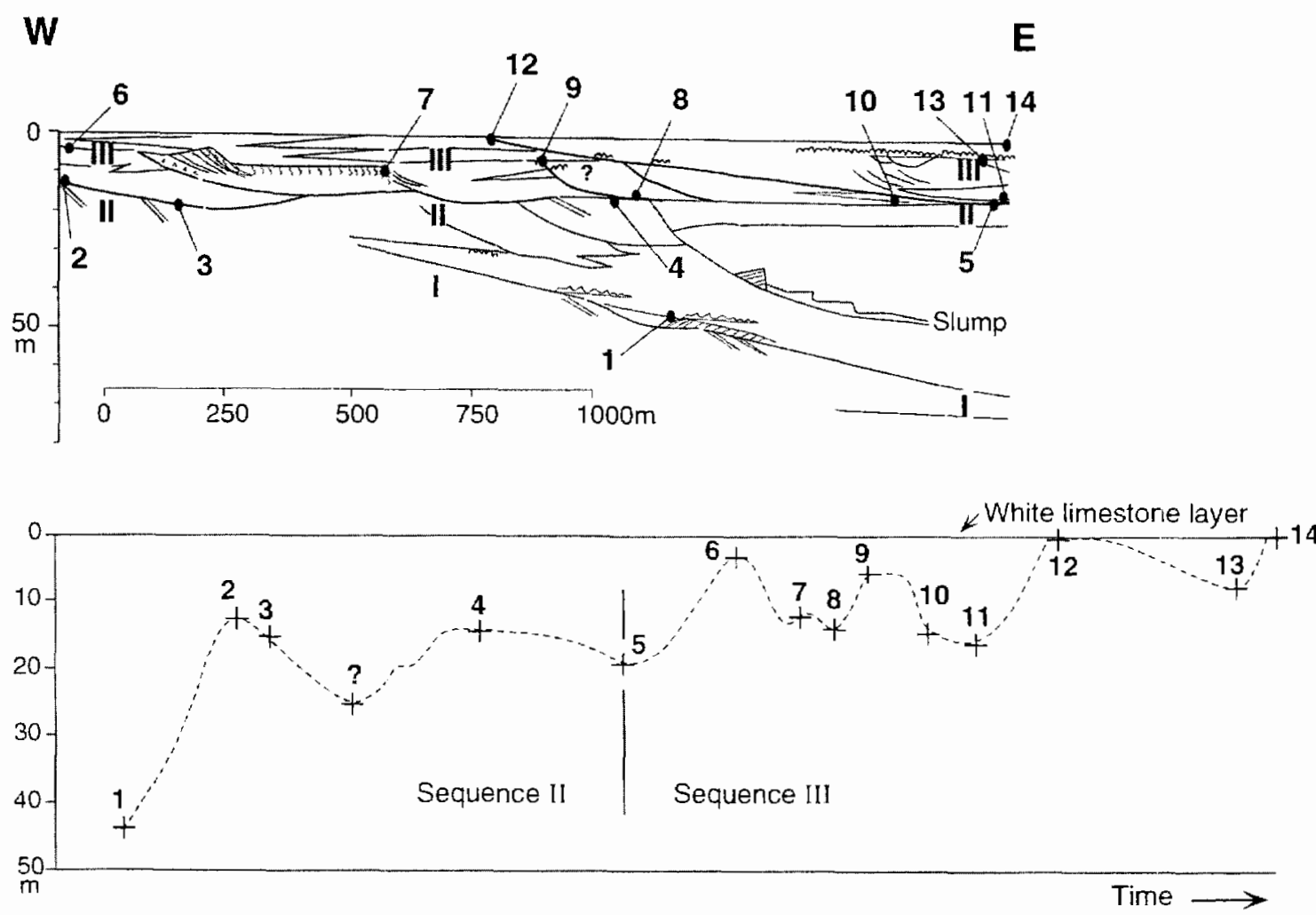

Fig. 9. Estimates sea-level fluctuations in sequences II and III through time relative to the position of the Zorreras white limestone datum plane. To facilitate description the sea-level positions $1-14$ are indicated on inset. Because of the unknown time constraints the distances on the time axis are arbitrary.

stand. From position 2 to 3 a sea-level drop of at least $3 \mathrm{~m}$ can be reconstructed in the top of unit II, between columns 1 and 2 (Fig. 6) using the overlying horizontally deposited lagoonal and washover sediments as reference level to measure the amount of seaward lowering of the top of unit II. In position 3 the swash zone came to rest directly on a deeper part of the coastal sequence with small-scale wave ripples and troughs. Further lowering of relative sealevel to $8 \mathrm{~m}$ is likely and even a lowering to $\sim 13$ $\mathrm{m}$ is possible given the locally exposed stromatolites (Fig. 6; columns 6A and 16). Together these stromatolites form a $\sim 200 \mathrm{~m}$ wide and up to $500 \mathrm{~m}$ long narrow ridge extending in a north-south direction. This indicates a time of non-deposition of siliciclastic sediments. The ridge has an irregular top and is overlain by sandy calcarenites of the upper shoreface and foreshore. The original water depth at which the stromatolites formed is uncertain. On one hand a thin correlatable limestone layer further east is lying directly on deep-water laminites, suggesting that the stromatolites of the ridge could have grown at $\sim 10 \mathrm{~m}$ waterdepth. On the other hand all other stromatolite occurrences in the Sorbas Basin are inferred to have grown in very shallow-marine and lagoonal settings. In case of a shallow origin it seems that during times of lowered sea-level with abandonment of a specific beach or barrier island the ridges were colonized by algae and stromatolite sedimentation thrived. Later, with return of the sea and renewed beach deposits, the exuberant growth of the stromatolites came to an end.

After the sea-level drop of 8 or $13 \mathrm{~m}$ from position 3 , it rose maximally $\sim 11 \mathrm{~m}$ to position 4 . A rise of at least $8 \mathrm{~m}$ can be reconstructed in two ways. First, from the superposition of two beachrock levels occurring $8 \mathrm{~m}$ apart along the path down to the Rambla de Cinta Blanca canyon (western entrance of Sorbas, Roep et al., 1979, their fig. 4, log 


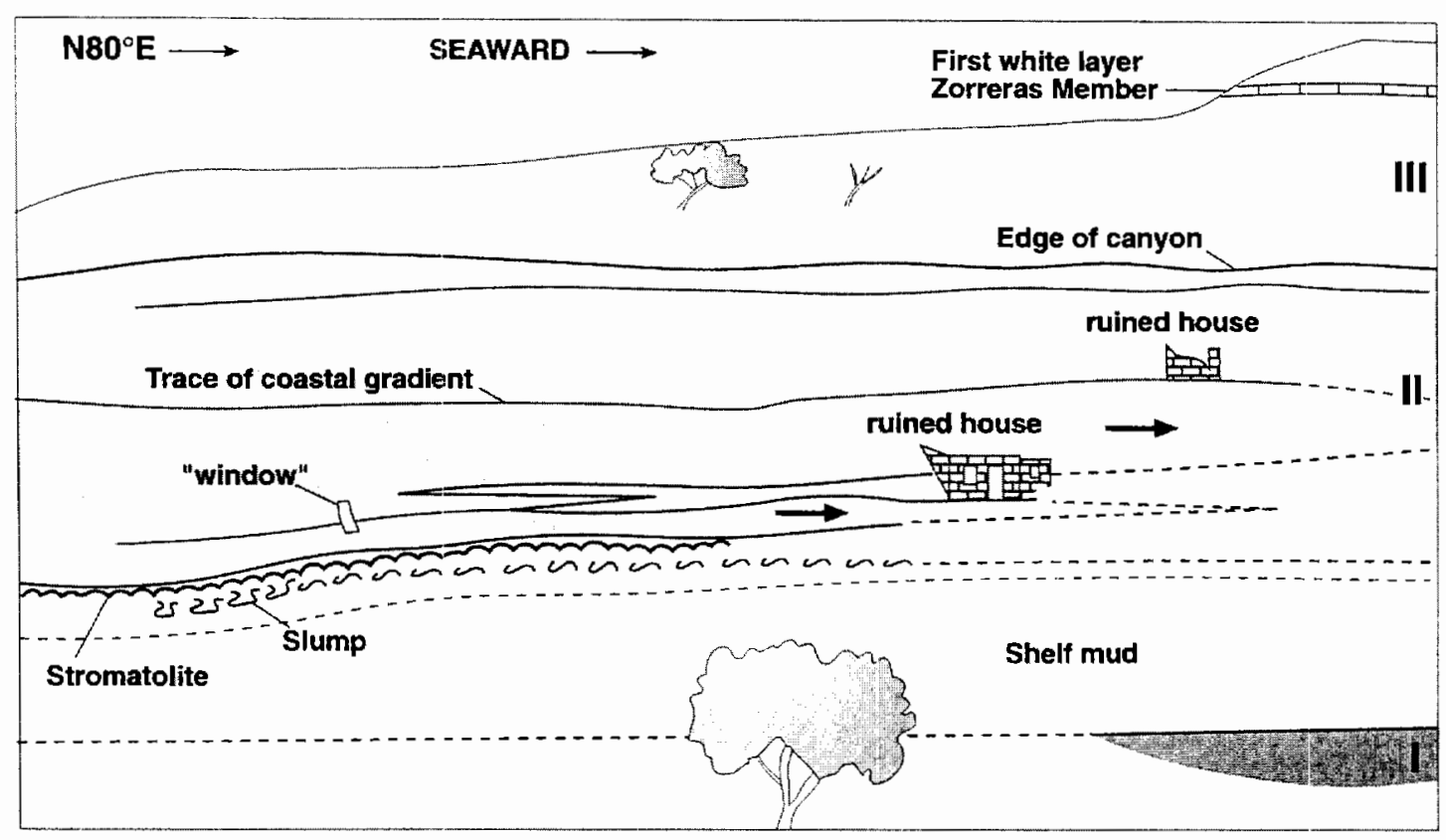

Fig. 10. Seaward (to the right) upstepping coastal wedges (sequence II, near section 8 ) due to a sea-level rise of ca. $8 \mathrm{~m}$, as exposed in the canyon wall of Rambla de Cinta Blanca, northwest of Sorbas (after photograph; height of canyon wall $\sim 15 \mathrm{~m}$ ).

A). A similar amount can also be deduced from the seaward upstepping of the toes of the sandy coastal sequence, interfingering with more muddy deeper deposited parts (Fig. 10), in the canyon wall north of the church of Sorbas (best seen from the Red Cross Station). Here, it is also possible to reconstruct the coastal gradient, by carefully following erosional and depositional surfaces (Figs. 5 and 10). It dips $\sim 3^{\circ}$, crossing the sandy part of the sequence. Usually, such gradients can not be observed in a prograding coastal sequence, due to irregular scours caused by fluctuating weather corditions and back and forward movement of the barrier. Roep et al. (1979) reconstructed this gradient using a heavily burrowed surface due to a temporary stillstand of barrier movement, or temporarily improved life conditions (decreased salinity).

After a major slump event, discussed in the next paragraph, sea-level remained more or less stable during progradation of sequence II (from position 4 to 5, Fig. 9).

Further basinward than the cross-section of Fig. 9, in an offshore mud setting, also evidence for fluctuating sea-levels can be found. Here, they are shown by
2-4 m thick thinning- and thickening-up sequences due to increasing and decreasing wave activity. Correlation with the prograded parts of parasequences I-III, however, is not always possible. In these sequences increase of wave activity due to shoaling is expressed as thickening-up sand layers with transition from lazy wave ripples to pointed wave ripples. Usually the thinning-up part of the sequential pattern is thinner than the thickening-up part. This is interpreted as a result of more slow, gradual progradation of the toe of the coastal slope (thickening upward) and a more rapid back-stepping of it during transgression (thinning upward).

Fluctuations of sea-level on a decimetre scale (and obviously of shorter duration) can be concluded from detailed analysis of the boundaries between the described facies of prograding beach barriers; in particular, interbedding of the facies types 5 and 6 in the idealized vertical sequence (Fig. 8) and the fact that the step at the lower shoreface indicates the sea-level (datum) at the time of deposition with a precision of centimetres (Somoza et al., 1986-87; Fig. 11). These oscillations are of comparable scale and dimensions as those known from half-century 


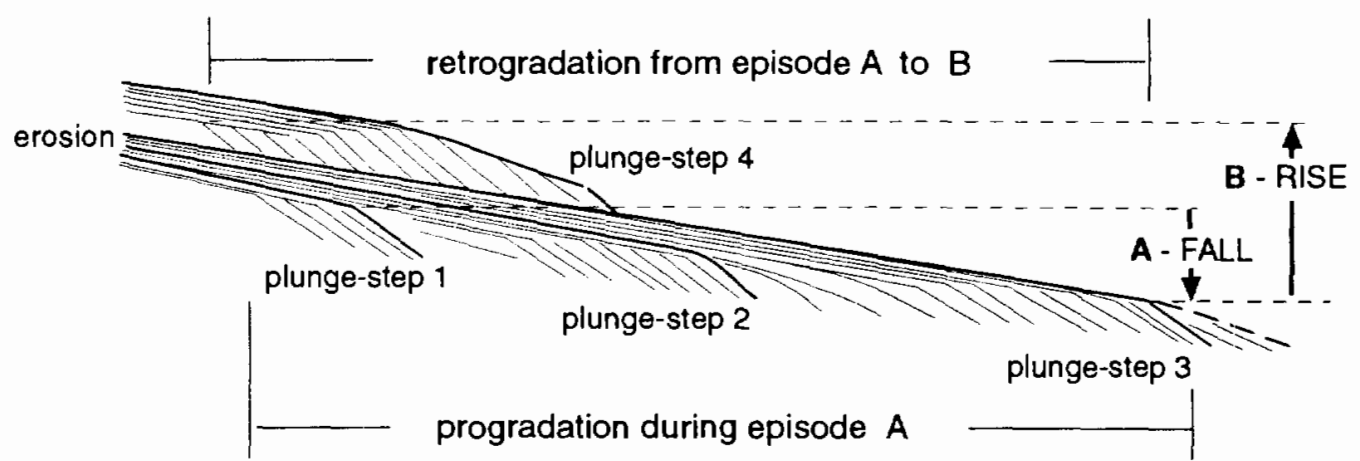

Fig. 11. Use of planar cross-bedding generated by seaward migration of the plunge step in the lower foreshore, to reconstruct beach progradation and retrogradation, and to deduce short-term trends of sea-level oscillations (modified after Bardaji et a1.. 1990).

minor fluctuations of sea-level, cited for southern Spain (Somoza et al., 1986-87; Zazo et al., 1994). Excellent examples can be observed near $\mathrm{km} 495.2$ at $\mathrm{CN} 340$ and near the springs of Sorbas, in this case within sequence I.

\subsection{Slumping and sliding}

At several times during progradation the coastal sediments were affected by large-scale slumping and liquefaction. As the Sorbas Basin is situated nearby major strike-slip faults that were active from Tortonian to Recent times such chaotic intercalations were probably triggered by earthquakes on a relatively steep slope, rather than by overloading and outbuilding of coastal sediments over shelf muds. Moreover, other indications for tectonically induced synsedimentary movements abound in the area. Some examples are given here. (1) Synsedimentary faulting and related cleavage blurring the original structures (sequence I, $\mathrm{km} \mathrm{496.5,} \mathrm{CN} \mathrm{340;} \mathrm{column} \mathrm{16,} \mathrm{Fig.} \mathrm{6).} \mathrm{This} \mathrm{zone}$ is sharply truncated by a swash zone in the top of sequence I. (2) Large-scale convolutions on a metre scale occur both in sequence I and II (sequence I near the eastern bridge of Sorbas, cf. Roep and Beets, 1977; sequence II near columns $11 \mathrm{~B}$ and 14, Fig. 6). (3) Large-scale fluidization structures on a scale of 2-3 m (road CN 340 at $\mathrm{km} \mathrm{497.3,} \mathrm{close} \mathrm{to} \mathrm{the} \mathrm{road} \mathrm{to}$ Lubrín). In the latter locality water escape took place along a line oriented $\mathrm{N} 10^{\circ} \mathrm{E}$. A few metres to the east, rotated blocks, associated with listric $\mathrm{N}-\mathrm{S}$-directed fault scars, indicate mass movement to the east.

The largest slump occurs in sequence II, at the eastern side of the village of Sorbas, where the seaward- slumped sandstone masses were used as foundation for the ceramic ovens and houses of the lower part of the village. The distorted sediments can be followed in the Rio de Aguas over about $1 \mathrm{~km}$ in a direction parallel to the original coastline (i.e. $\mathrm{N}-\mathrm{S}$ ) and over more than $400 \mathrm{~m}$ at right angles to it, before younger sediments cover the exposure (Fig. 4a). Most likely, the original slump scar was oriented $\mathrm{N}-\mathrm{S}$ along the present eastern edge of the mesa on which the village has been built. Part of this slump may also be the slump scar exposed $600 \mathrm{~m}$ northeast of the church of Sorbas in the Rio de Aguas, where it is situated in the wave-rippled original shoreface, that was subsequently healed by rippled sands.

After the slumping, progradation continued, but obviously the barrier never recovered from these changes: the sandy part of the prograding sequence became thinner and finer grained; the muddy, waverippled part thickened and more contorted bedding occurred in younger parts further east. These side effects seem related to such a degree of tectonically induced change that either an overall decrease of fetch occurred, or that some shielding from wave activity was provided. Also increased subsidence and instability of the basin margin must be taken into account.

\section{Sequence III}

\subsection{General}

The total thickness of this sequence of $\sim 20 \mathrm{~m}$ implies that during its deposition water depth cannot have exceeded $20 \mathrm{~m}$ and generally was less $(\sim 10$ 
$\mathrm{m})$, regarding the height and position within it of bird-foot tracks, swash zones, beach-rock levels and thickness of prograding units (Fig. 6). Sequence III exhibits the most complex architecture due to interrupted progradation, which resulted in an intricate pattern of juxtaposed and superposed lagoonal muds, washover fans and swash zones. The swash zones belong either to 'stranded' coastal barriers, left behind after seaward jump of the coastline during regression, or are connected with erosional parts of the coastline at the cost of landward-lying washover sediments, or belong to a prograding coastal sequence. This more complex geometry is evidently related to a more limited accommodation space, when minor relative sea-level fluctuations have great influence. Slight regressions, for example, rnay cause an offshore bar to build up quickly near or above sea-level, after which the coastline jumps seaward.

The western part of the facies diagram (Fig. 5) shows that large parts of the original space was filled up by lagoonal sediments and washover fans, which show thinning and up-stepping in a landward direction. In the parallel laminated lagoonal muds mud cracks, raindrop imprints, salt pseudomorphs, insects, rootlets and plant remains and animal tracks (birds: crane, rale, plover and of a wolf or lion) have been observed (Roep and Beets, 1977; Roep et al., 1979; J. Kenter, pers. commun., 1984).

\subsection{Estimates of sea-level changes}

After deposition of sequence II, sea-level rise initially must have been in the order of $16 \mathrm{~m}$ (shifting from position 5 to 6 in Fig. 9). This rise is indicated by the thickness of washover fans in the west and position of beach-rock breccia in sections 2 and 3 (Fig, 6). Because the latter overlie the washover fans erosively, a landward shift at the cost of the washovers is indicated. Associated with the thick layers of beach-rock breccia is a well developed swash zone (exposed along N 340 at $\mathrm{km} \mathrm{495.4,} \mathrm{some}$ $300 \mathrm{~m}$ west of Sorbas; Fig. 5, section 3). This swash zone is part of a small elevated ridge, which can be followed to the south over more than $1 \mathrm{~km}$ (Fig. 4) and interpreted as a 'stranded barrier'. This barrier (Fig. 12) implies a relatively deep sea in front of it to the east (a space now occupied by the washover fans west of km 596.1, Hostal Sorbas; Fig. 13). After its formation an important seaward (regressive) jump must have occurred, related to an estimated

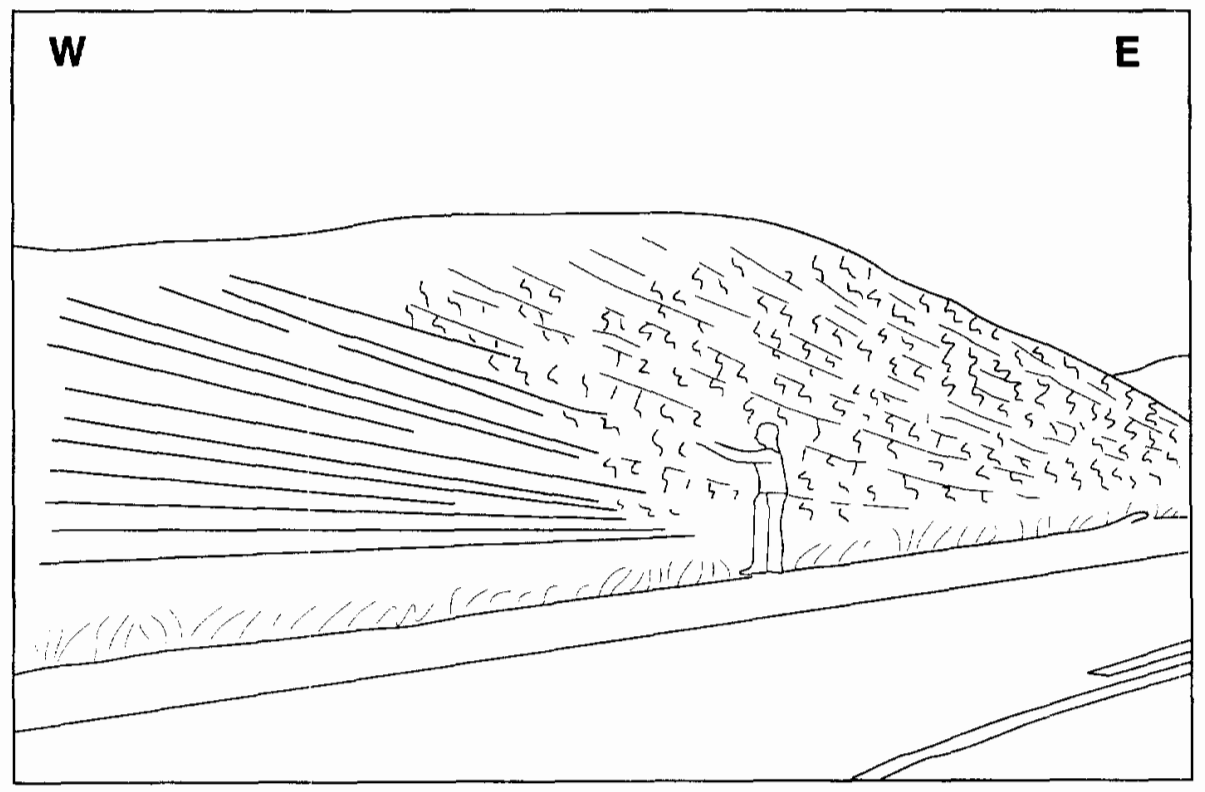

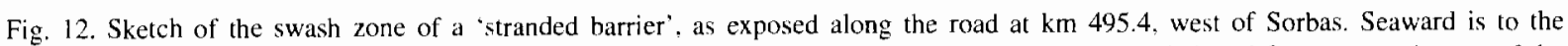
right. Due to seaward jumping of a new barrier progressive shielding to wave activity in this bar is inferred from steepening-up of the low-angle swash lamination (pointed at by the geologist) and increase of burrowing, causing blurring of the stratification (to the right). 


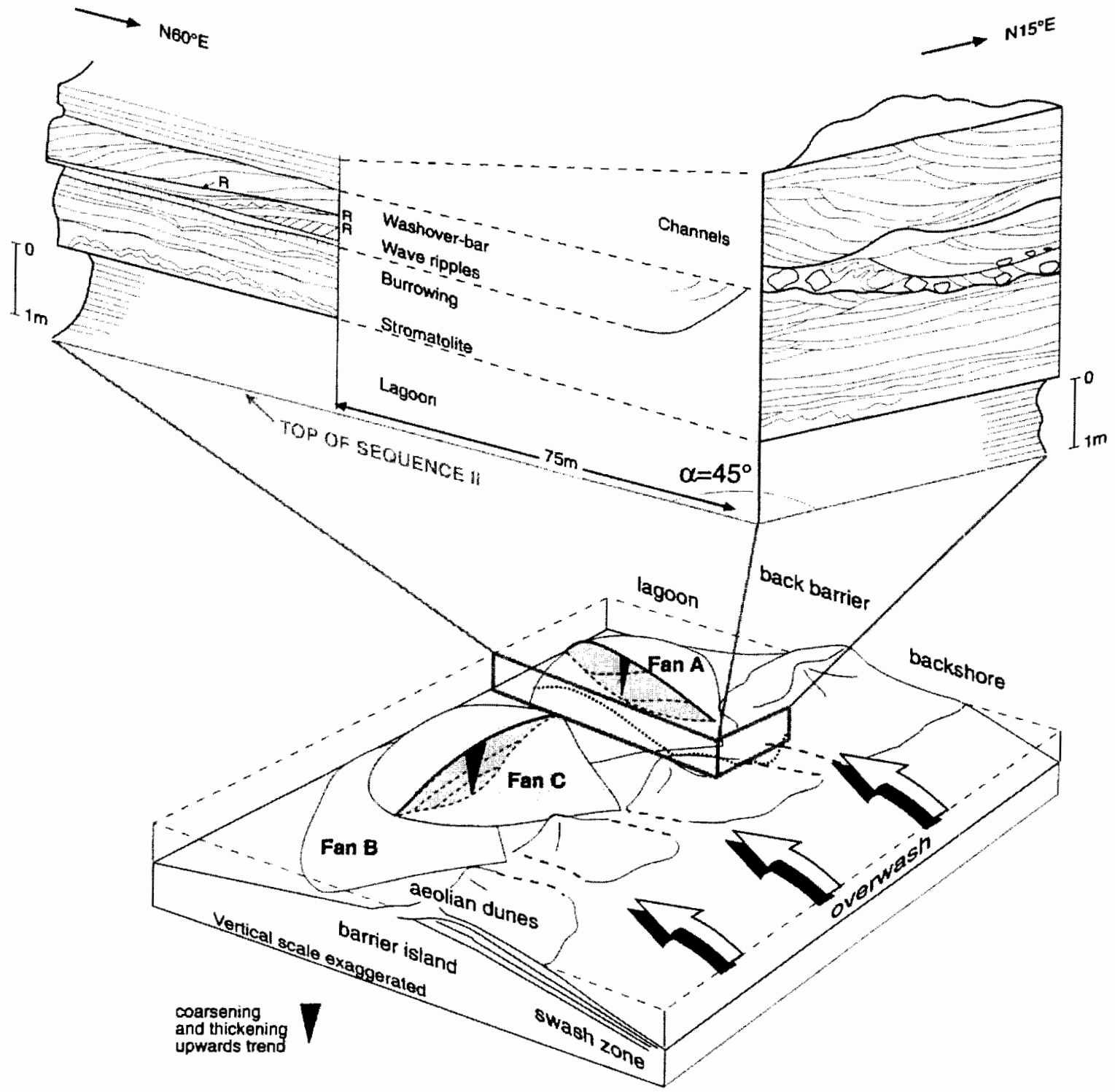

Fig. 13. Location details of washover fan deposits (upper figure), showing landward thinning (to the left). The proximal part (to the right) shows stacked channels and coarse intraclast lag deposit. At the distal part the washover bar shows episodic shift $(R==$ reactivation surface). Occasionally former bar fronts show wave ripples (oriented $\mathrm{N} 300^{\circ} \mathrm{E}$ ) indicating a shallow lagoonal setting after a storm event causing landward shift of the bar front. Low-angle, high-angle and sigmoid cross-beds in the bar indicate westward sand transport. The bottom figure shows a conceptual model of washover development during relatively slow sea-level rise (modified after Dabrio et al., 1996). A series of laterally and vertically stacked washover-fans is formed due to repeated overwash at laterally disconnected spots of the barrier. Compare with Fig. 7.

sea-level fall of altogether $\sim 14 \mathrm{~m}$. The swash zone clearly shows its deterioration (Fig. 12) by a basinward-increasing steepness of the swash lamination associated with finer grain size and increasing bur- rowing, in part within the swash lamination itself. The forced regression was accomplished in several steps with temporary stillstands, small rises and erosion events. Slight erosion may have taken place 
(for example indicated by the sharp contact between a coarse-grained conglomeratic swash zone and the top of an intensely burrowed upper part of a sandy coastal sequence in the riverbed of Rambla de Cinta Blanca (Fig. 6, columns 4 and 5; Fig. 9, position 7).

The stranded barrier and regressive seaward part is onlapped by an up to $20 \mathrm{~m}$ thick pile of washover fans, indicating renewed transgression (Fig. 5). These deposits seem to be the result of two transgressions interrupted by a forced regression, leaving behind a second stranded barrier (marked '?' in between sea-level positions 8 and 9, Fig. 9, because not all sedimentological details could be clarified). This second stranded barrier can be followed in N$S$ direction along two paths descending along the cliffs from both the NW and SW corner of the town. From position 9 (Fig. 9) a forced regression caused an eastward shift to 10 , after which renewed transgression proceeded from 11 to position 12. The transgressive surface is well exposed in the first curves along the road to Lubrin $(\sim 100$ $m$ west of section 14, Fig. 6) and is marked by a beach-rock breccia and a thinning-up wave-rippled sequence. This ravinement surface can be followed further westward in sections 13,12 and 11B (Fig. 6), in which direction the transgressive sequence thickens into a wedge-shaped sandbody characterized by wave-formed megatroughs. This unit is interpreted as the toe of a transgressed barrier. Further west the transgressive surface is lost in the canyon of the recent Rio de Aguas, but can be picked up again in sections 10, 15 and 7 (Fig. 6).

After this transgressive episode progradation was resumed and the sea-level shifted from position 12 to 13, marking a small lowering (of $\sim 8 \mathrm{~m}$ ) and then shifted to 14 (marking a final small transgression, with deposition of lagoonal mud, washover sandstone, beach-rock breccia, oolitic limestone and stromatolites). It is clear to us that the mean sealevel rose hardly enough to cover a coastal zone with topographical irregularities, thus providing little accommodation space. Even small fluctuations were able to produce a variety of depositional patterns.

Hereafter, the Messinian sea definitively withdrew from the area around Sorbas. Its latest influence can be studied $4 \mathrm{~km}$ to the east of Sorbas (south of km 501.6 at CN 340, Roep and Beets, 1977; Roep and Van Harten, 1979). Here a sea-level drop of at least $15 \mathrm{~m}$ is inferred from the most basinward deposited sequence. Offshore muds with only the slightest traces of wave activity are directly overlain by a slump of $1 \mathrm{~m}$ thickness, followed by a $3 \mathrm{~m}$ thick gravelly beach- or washover-sequence, which in turn is overlain by continental strata of the Zorreras Member. In the top of the Sorbas sequence a 'pisolitic layer' occurs (see also Section 11), which can be correlated over $3 \mathrm{~km}$ with the stromatolites at the top of unit III, column 14 (Fig. 6). This correlation indicates that most of the time this basinal section was well below wave base.

\section{Sequences in washover fans}

Many good examples of landward-thinning and upstepping washovers can be found in the Sorbas area, such as near columns 1-2, 6B-7 (Fig. 6) and at the northwest corner of the town, as can be seen from the Red Cross Station (Roep and Beets, 1977). Sedimentary details are shown in Fig. 13. In a vertical sense, such successions may be thought to show mainly a thickening upward, because of the transgressively advancing coastline. However, such a simple sequential order is not maintained. We observed both thickening-up, thinning-up and irregular sequences. Rather the picture emerges of compensation cycles, as described by Mutti and Sonnino (1981) for submarine fan lobes. The following scenario is inferred: at places where a barrier is pierced during storm, relatively thick stacks of washover fans accumulate at the proximal side (Fig. 13). Owing to their fan shape they thin away from the breach, distally towards land and proximally towards the parts of the barrier where the barrier was not broken. Later other bed thickness trends may develop in case the barrier island is broken or surpassed in different places. This, coupled with variable rates of sea-level rise, will produce diverse types of large-scale cross-bedding in the landwardmigrating back-barrier (Figs. 7 and 13).

With regard to hydrocarbon exploration it is interesting to note that the sandstone connectivity in a transgressive setting with lagoon and washover sediments is quite different from one with a tidal inlet and inner delta. In the latter case the barrier sands are deeply eroded by the inlet channel, whereas in the case of washover channels erosion is very modest (Fig. 13). In the case of the Sorbas examples 
both marine mud tongues and lagoonal mud tongues, which respectively pinch out landward and seaward, would act as a permeability fence (Fig. 5). Due to the reduced accommodation space in sequence III transgressive washover girdles occur in juxtaposition with regressive, erosive 'stranded barriers'. This setting therefore may both reduce and enhance lateral fluid migration. Stromatolitic intercalations further reduce the permeability.

\section{Source area of extra- and intra-clasts}

Because of prominent lithological differences between the various deposits in the beach zone, some attention should be given to the source areas of sediments in the coastal barriers, lagoon, and washovers as compared to the offshore facies.

The beach deposits comprise both calcarenites with coated grains and oolites mixed with coarser grains (gravels), in part of terrigenous origin. Many coarser fragments are flat-rounded calcarenites, one to several centimetres in diameter, and were derived from within the barrier during beach retreat. Usually they are associated with erosional surfaces and washover channels. Particularly the larger pebbles may derive from eroded beach rocks.

The offshore sediments are mostly siliciclastic, fine micaceous sandstones, silts and clays. Some layers are dark grey due to abundant organic matter. Interbedded wave-rippled, undulating laminated, parallel-laminated, and some small-scale hummocky cross-bedding-like layers of laminated sandstone and calcarenite represent storm layers. Intervals of waveripple cross-lamination or parallel-lamination occur depending on water depth. Lack of burrowing in many levels suggests oxygen depletion and/or abnormal salinities and especially characterizes the deeper offshore muds. Marine fossils are either $a b-$ sent in these deposits, or few specimens are found of which the autochthonous nature is questionable (Ott d'Estevou, 1980).

The lagoonal deposits consist of yellow and white parallel laminated silt and clay with interbedded thin $(1-3 \mathrm{~cm})$ layers of fining-upward sandstone. Sediments of the wedge-shaped calcarenite layers of washover-fan facies are derived from the barrier. This implies multiple sediment sources and therefore requires coastal processes (Fig. 14) such as: (1) streams supplying siliciclastics of variable grain size; (2) in-situ precipitation of carbonate as oolites, coated grains, stromatolites and thrombolites (this probably under a warm climate, as suggested by occurrences of halite pseudomorphs in lagoonal muds); (3) littoral drift (along-shore currents) transporting sediment into the barrier from sources that, according to their lithology, were located to the north.

\section{Tectonic factors controlling the location and development of barrier islands and lagoons}

Next to relative sea-level changes and differential uplift, also related geometrical factors such as gentle

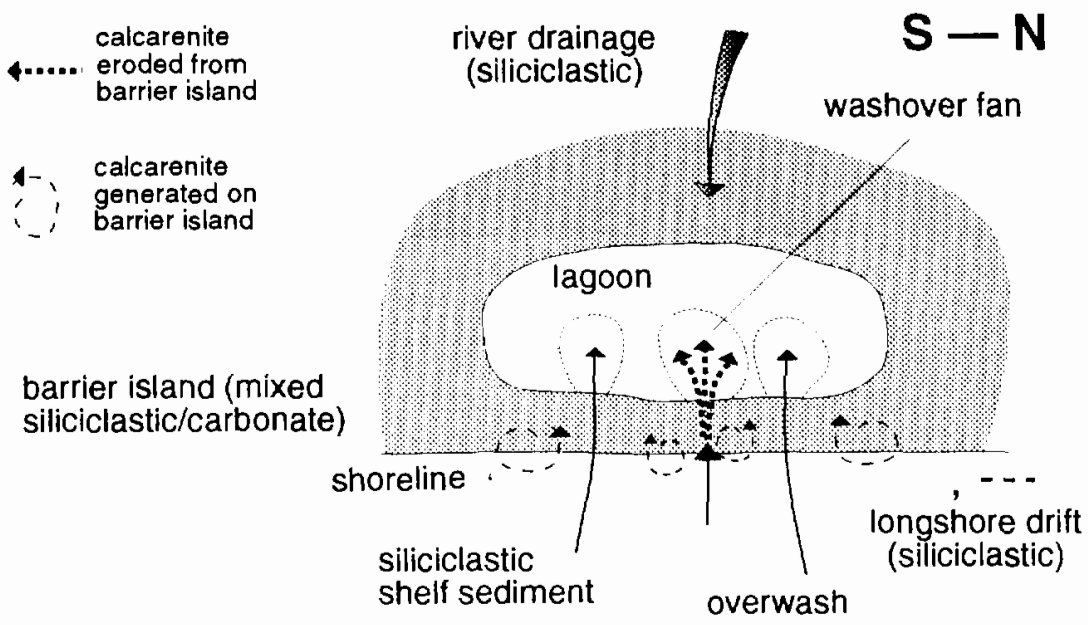

Fig. 14. Sketch of inferred sediment circulation in the barrier island and lagoon systems of Sorbas. 


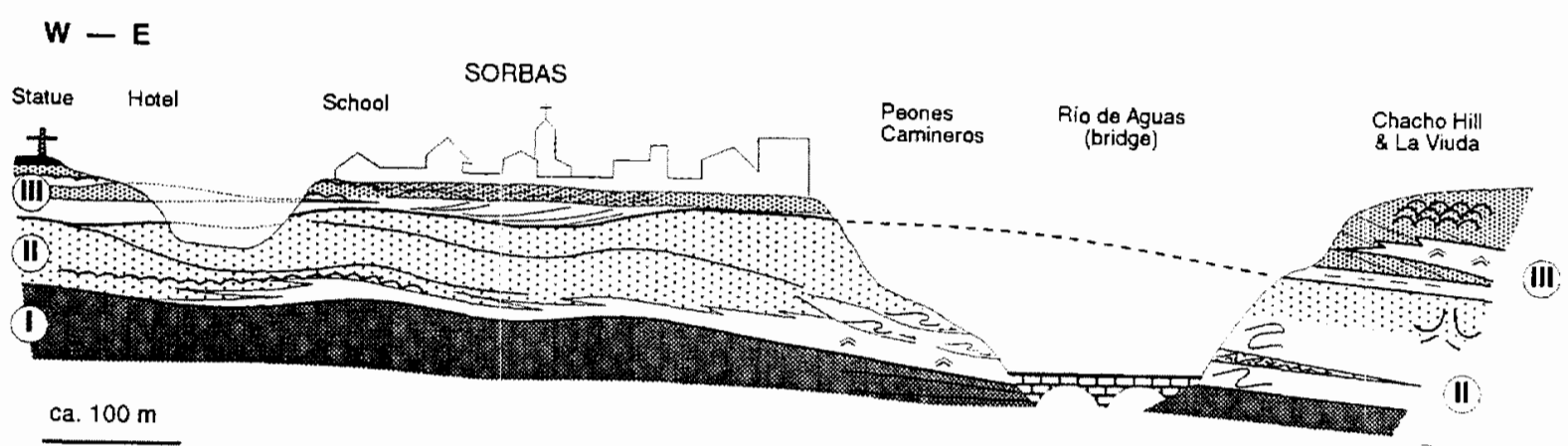

Fig. 15. Schematic W-E cross-section of the coastal units of the Sorbas Member in the cliffs of Sorbas. The section is roughly normal to the palaeocoastline and shows the influence of minor, approximately $\mathrm{N}$-S-oriented syndepositional folds. Compare with panorama in Fig. 4b.

and locally occurring synsedimentary folding appear to have influenced the stratigraphic architecture of the Sorbas Member, notably the prominent $\mathrm{N}-\mathrm{S}$ orientation of the beach ridges and lagoons. Initially, it was assumed that this direction was related to the angle of incidence of waves under prevailing winds. Although this is probably a large part of the explanation, increasing knowledge of the geometrical relations made it clear to us that at least part of the palaeogeographical trends must have been induced by subtle tectonic deformation. Most of this type of deformation occurred during and after the deposition of sequence II. A view on such a structure can be obtained along the provincial road ( $\mathrm{CN} 340, \mathrm{~km} 496.3-$ 496.8, Fig. 15). Here (from km 496.4 visible below the school), the existence of such slightly depressed, or elevated narrow zones is further suggested by the pinching out of lagoonal deposits against the gentle palaeoslope, both to the east and southwest in unit III. The very gentle folding with a roughly $\mathrm{N}-\mathrm{S}$ axial direction visible here, seems to be associated with a conjugate set of secondary antithetic NW-SE and synthetic NNE-SSW shears, reported by Mather and Westhead (1993) and Stapel et al. (1996). Regional palaeostress analysis (Biermann, 1995; Stapel et al., 1996) indicates a maximum principal stress axis orientation of $\mathrm{N} 350^{\circ} \mathrm{E}$ for the late Messinian to Late Pliocene sediments of the Sorbas Basin, which was synchronous with sinistral motion along the Palomares fault zone (Fig. 1). Recent NW-SE faults crossing Sorbas are visible and measurable in the walls of the houses and the church, and also in road CN 340. Mather and Westhead (1993) observed also in Plio-Pleistocene Sorbas locations minor N-S trending, but variably oriented folds and noted that their genesis could have been stimulated by the underlying evaporites. It is interesting to note that the fluidization structures and slumps cited in unit II also are bound to $\mathrm{N}-\mathrm{S}$-oriented faults and slide scars.

The creation of a roughly $\mathrm{N}-\mathrm{S}$-trending ridge and swell morphology around Sorbas had palaeogeographic implications: the rising areas ('anticlines') acted as nucleation areas for barrier islands, whereas the intervening gentle depressions favoured the development of lagoons. One of the main effects was the generation of a slightly subsiding zone just below Sorbas town where lagoon and washover fans are best developed.

A crucial point is that the (present) difference in elevations between these areas is usually 3 or $4 \mathrm{~m}$, and most of the irregularity was compensated after deposition of unit III. Thus, the lowermost lagoonal calcareous layer of the Lago Mare facies, used as reference line in Fig. 5, is a horizontal surface. The moderate accommodation space added to the topographically slightly irregular floor of the basin promoted the jumping character of the barrier islands during deposition of unit III.

\section{Relations with the terminal carbonate complex}

The TCC of the northern margin of the Sorbas Basin consists mainly of siliciclastic fluvially 


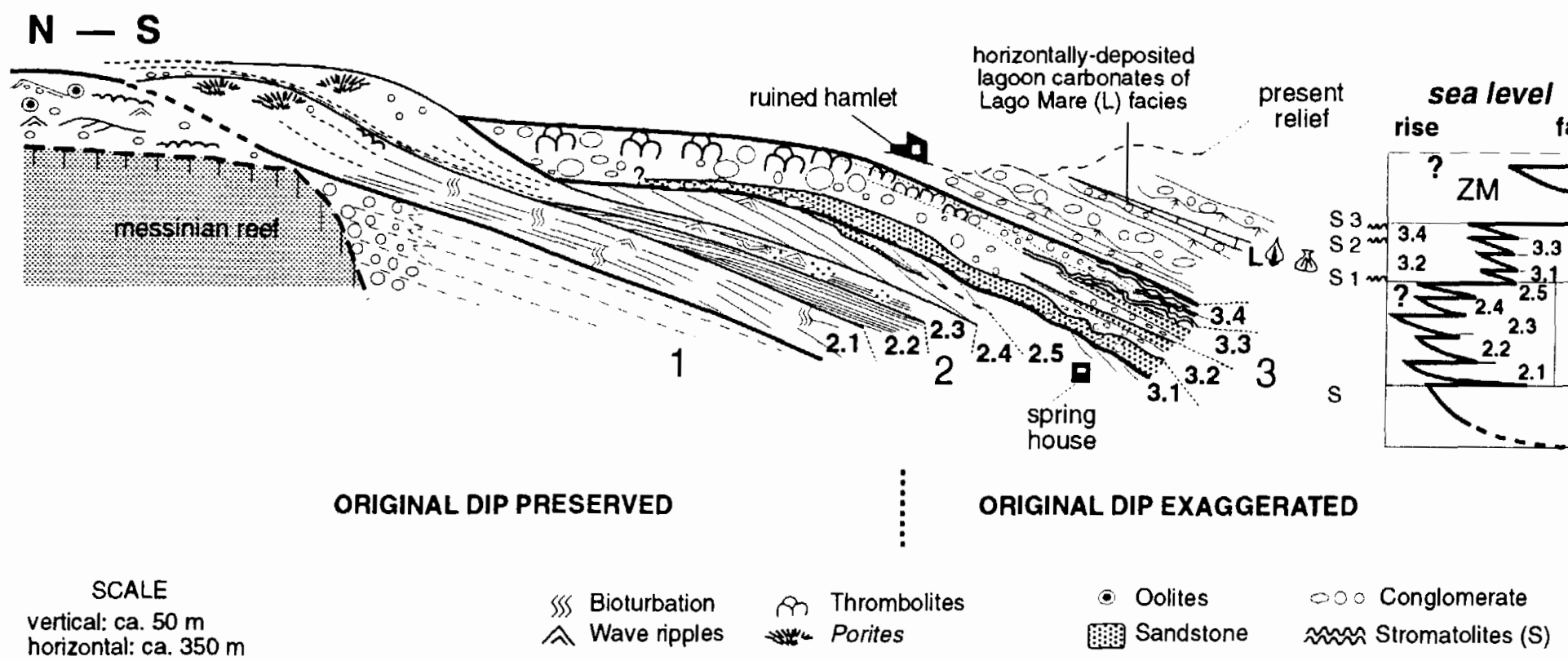

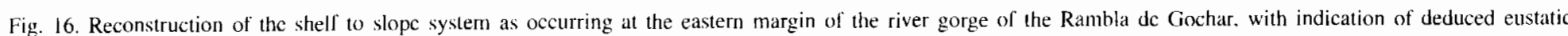

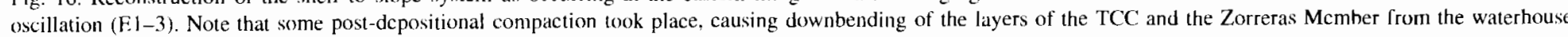
to the south (modified after Dabrio and Polo, 1995). 
derived coastal conglomerates that change laterally into sands. Both the conglomerates and the sands are intercalated with oolitic limestone, small Porites patch reefs, and microbial carbonates (stromatolites and thrombolites). These coastal to slope units are arranged in a complex offlap pattern (Dabrio and Polo, 1995; Fig. 16).

Martín et al. (1993) described the features of the Messinian siliciclastic microbial carbonates in detail and interpreted them as a normal-marine facies, shown by Porites within the domes (some bored by Lithophaga), algae, including coralline algae, vermetids and encrusting forams. A significant part of the present stratal dip, however, is a post-depositional feature (Fig. 16), and not an original one, as argued by the latter authors to justify the role played by the original slope in controlling the morphology and distribution of stromatolites. Post-depositional compaction and tectonics account for the exaggerated dip of the younger beds of the TCC and the Zorreras Member (including the originally horizontally deposited white 'Lago Mare' limestones) in the southern part of the outcrop. Differential compaction, due to the limited extension toward the basin of the underlying cemented reefal limestone may have played a major role.

An important aspect of the TCC is the obvious sequentiality. In the outcrop of Gochar it comprises three major units of decametre scale, which consist of thinner metre to decametre scaled coarsening-or thinning-upward sequences (for details, see Dabrio and Polo, 1995).

Unit 1 of the latter authors (Fig. 16; or parasequence $I$ according to the present terminology) consists of a variety of facies: coastal conglomerates and wave-rippled oolitic limestone, poorly preserved stromatolites and conglomerates that change basinward into sands.

Unit 2 includes at least five prograding units, two of which (2.1 and 2.3) are related to Porites patch reefs. Stromatolites draped a part of the patch reefs, in particular the talus facies consisting of calcarenites and calcisiltites. These form metre- to decametre-size coarsening-upward sequences: laminated mudstones at the base pass upwards into wave-laminated medium to fine sands (storm sand layers), and burrowed wave-ripple cross-laminated and cross-bedded calcarenites and sandstones. Lo- cally, Ophiomorpha burrows and water-escape structures occur. Dabrio and Polo (1995) interpret these sequences as a result of upward aggradation and progradation of fan-shaped units, some of them connected to topographically more elevated patch reefs, during minor fluctuations of sea-level (Fig. 16, right hand column).

Unit 3 mainly consists of layers of conglomerate, sand and stromatolite/thrombolite. Large-scale wave-ripple cross-stratification occurs in the lowermost part (supposedly 'deeper' part of the talus slope in the opinion of Martín et al., 1993). The metre-size sequences essentially show a basal erosional surface, followed by conglomerates, wave-ripple cross-stratified and cross-laminated sandstones, overlain by thin-bedded, parallel-laminated sandstones passing upward into stromatolites (three levels found, indicated SI-3 in Fig. 16, right hand column). According to Dabrio and Polo (1995) these sequences are related to high-frequency eustatic cycles, in which the stromatolites indicate the end of a highstand. The authors suggested that the thinner sequences might be related to oscillations of sea-level of higher frequency than in unit 2, and acting on a surface much less inclined than in unit 2 (in fact it would be almost horizontal).

Most importantly, Dabrio and Polo (1995) correlated the Gochar sequences from the northern basin margin with those from Sorbas (Fig. 17). With regard to the relative sea-level reconstructions presented in Fig. 9, we now consider it likely that the major sealevel excursions for parasequence II (points 2 and 4) correlate with the highest, stromatolite-capped sequences (2.1 and 2.3, Fig. 16) of Gochar. Similarly, the four fluctuations concluded for Gochar in unit 3 (Fig. 16) might well be the equivalents of points 6 , 9,12 and 14 of sequence III, Fig. 9.

\section{Late Messinian retreat of the Sorbas sea}

As one of the Mediterranean marginal basins, also the Sorbas Basin underwent the complex series of depositional events related to the much discussed Mediterranean Messinian salinity crisis (Hsü et al., 1973, 1977). Very briefly summarized this crisis comprises the following major steps. (1) Restricted watermass exchange with the Atlantic ultimately resulting in evaporite deposition in the marginal basins. 


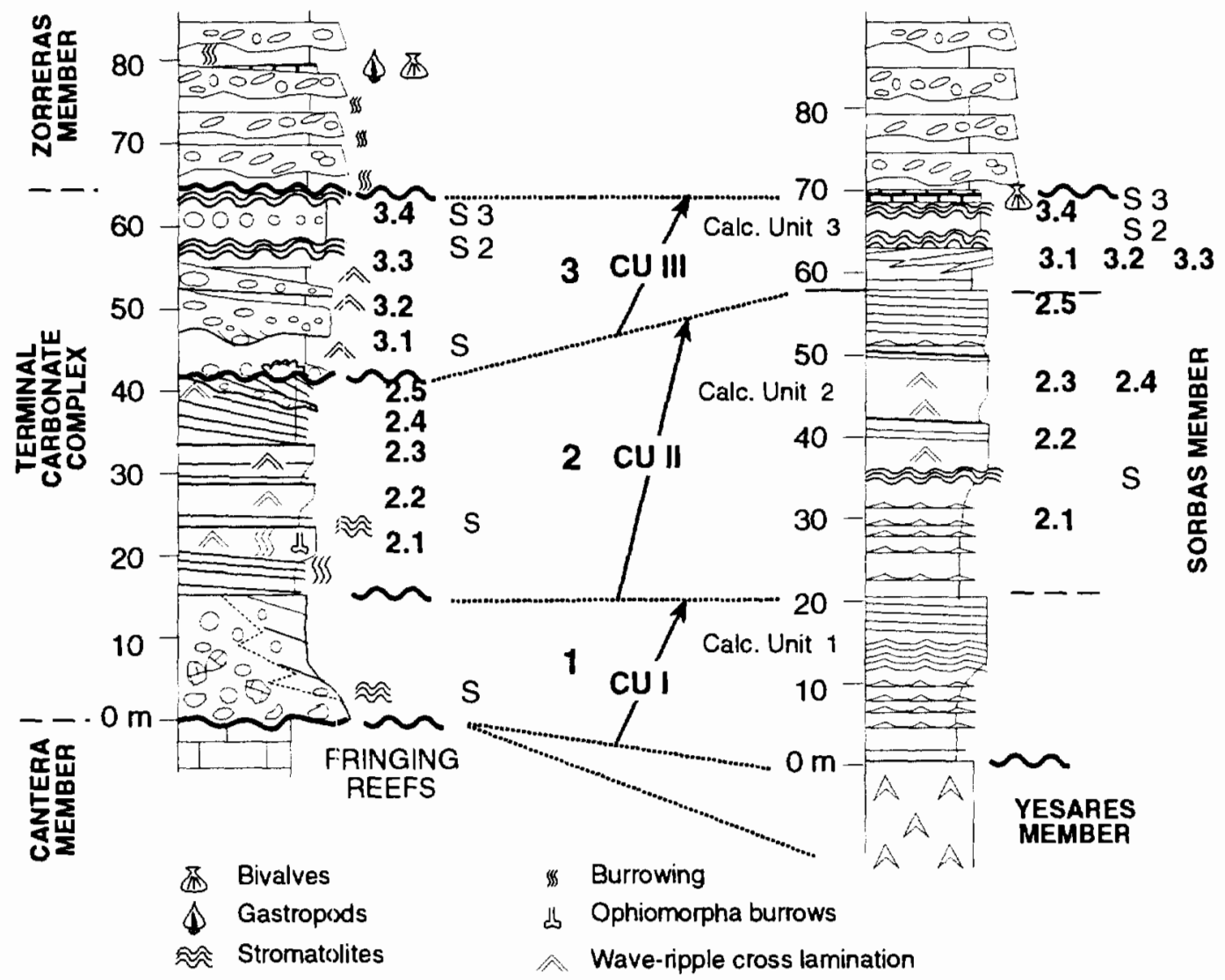

Fig. 17. Synthetic succession of the Sorbas strata and suggested correlation of the three sequences with the synthetic section of Rambla de Góchar at the northern basin margin ( $S=$ stromatolite layer). Note that wedge-shaped units make vertical scales in Góchar inaccurate. (Modified after Dabrio and Polo, 1995.)

(2) With complete closure from the Atlantic a major desiccation phase occurred with a proven sea-level drop exceeding $2000 \mathrm{~m}$ (Stampfli and Höcker, 1989). (3) The salinity crisis ends with deposition of a transgressive brackish, so-called Lago Mare facies which may have involved supply of Paratethyan waters. (4) The return to normal marine waters was reestablished by opening of the Gibraltar passage at the onset of the Pliocene.

The Sorbas Basin, with its well known gypsiferous sediments underlying the Sorbas Member, however, does not clearly expose traces of a major intra Messinian sea-level drop that can be related to the late Messinian desiccation event. In fact, the factors governing the final retreat of the late Messinian
Sorbas sea so far have mainly been a matter of speculation (summarized in Van de Poel, 1994). Where then to find the intra-Messinian downdrop traces in the sediments of the Sorbas Basin: below or above the Sorbas Member? Traces of this widely reported sea-level drop (see recent discussion by Clauzon et al., 1996) are hard to find. In case the sea forming the Sorbas Member already belonged to the terminal Messinian Lago Mare event, as suggested by Van de Poel (1994), it would postdate the down drop event'. At least the Zorreras Member, which includes the white lagoonal beds with 'Lago Mare' fauna, is a post-downdrop unit.

After the major downdrop of the Mediterranean, Porites and other reef-building corals never returned 


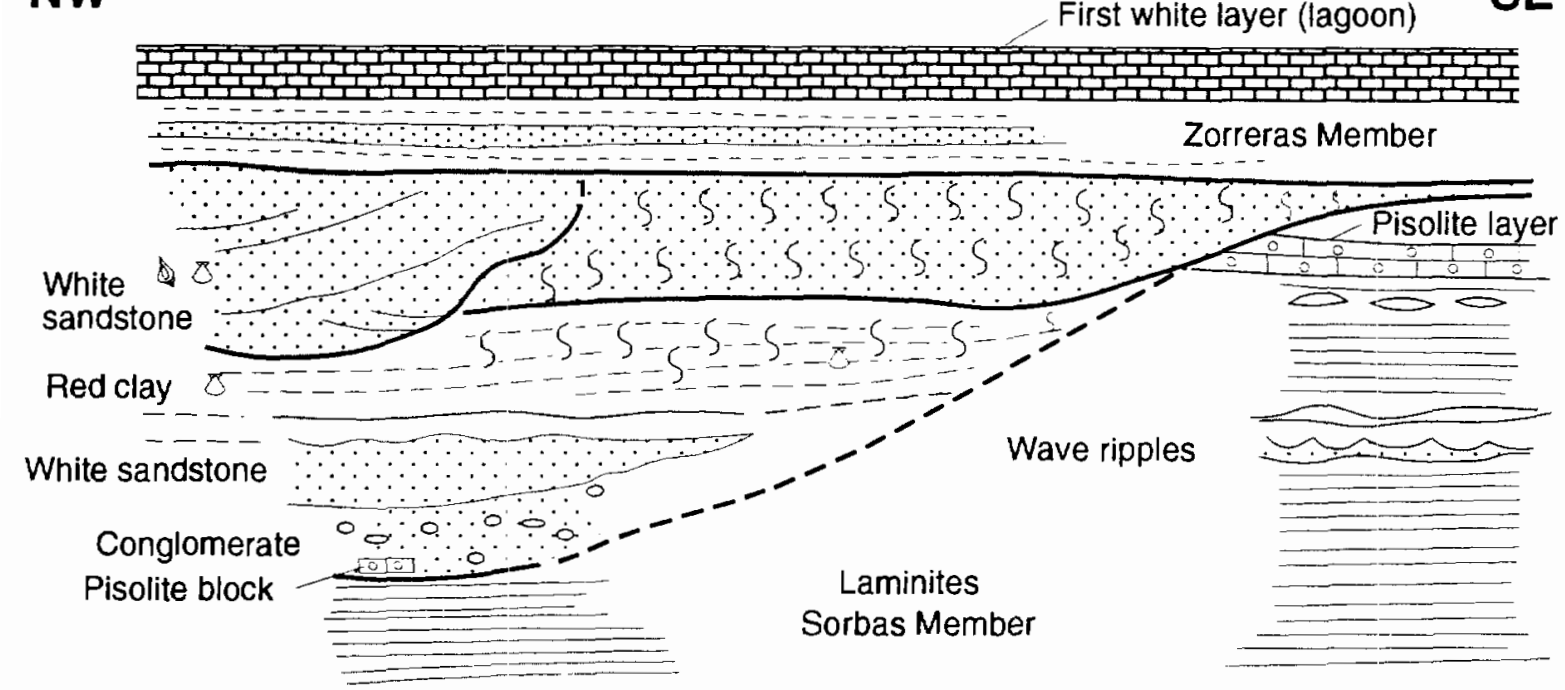

Fig. 18. Reconstructed channel incision ( $\sim 6 \mathrm{~m}$ deep) occurring at the top of the Sorbas Member near $\mathrm{km} 499.5$ and possibly the local expression of the lowstand due to the late Messinian Mediterranean desiccation event. The channel is overlain by pink clay and sands, plus the first white 'Lago Mare' bed of the Zorreras Member. The channel has a complex infill consisting of pebble conglomerate with a block reworked from the eroded pisolitic layer and white sandstone at the base. The upper part includes mottled red clays and silts, bioturbated white sandstones and a smaller channel-fill (with Hydrobia and small shells of 'Lago Mare' affinity).

to it (Esteban, 1979). The finding of stunted Porites above a layer of selenite gypsum west of the road to Lucainena (Fig. 1), in association with oolitic limestone in a marginal Sorbas Member setting not only confirms a TCC connection, but also indicates deposition before the downdrop event. This implies, at variance with Rouchy and Saint Martin (1992) and Martín and Braga (1994, 1996), that the major intra-Messinian unconformity occurring between the fringing reefs and the TCC at the basin margins, more likely reflects the result of regressions coupled with deposition of the evaporites in the marginal basins, than the major desiccation event. Presence of conformable contacts between both the Yesares evaporitic strata and the underlying open marine Abad sediments and the gradual YesaresSorbas Member contacts, are interpreted as indications that the Sorbas Member is a pre-downdrop unit than can be correlated with the TCC (Fig. 17). Thus, in our vision traces of an important downdrop event first of all should be sought within or at the top of the Sorbas Member. A locality in the basin centre showing an erosion event at this stratigraphic level, underlying the Zorreras Lago Mare bed, and therefore the most likely candidate representing this event, will therefore be discussed (Fig. 18).

Large amounts of thin shells and Hydrobia of Lago Mare origin can both be found in the topmost layers of white Sorbas sandy calcarenites along the road to Lucainena and in a small gully (east of the ruins of the Venta de la Lencia) near $\mathrm{km}$ 499.5. In this latter locality the shells occur in a channel cutting into the 'pisolite layer' (Roep et al., 1979), a bed consisting of small irregular algal balls, probably green algae. The channel is $\sim 6 \mathrm{~m}$ deep. The pisolite bed could be traced from the centre of the Sorbas Basin (near km 501) to the Lubrín road (at $\mathrm{km} \mathrm{497.3),} \mathrm{where} \mathrm{it} \mathrm{merges} \mathrm{into} \mathrm{the} \mathrm{uppermost}$ stromatolites of section 14 .

Such minor evidence for local erosion during a sea-level fall in the Sorbas Basin centre suggests that in fact the basin centre never was deeply eroded. Perhaps a palaeogeographic barrier between the Sorbas Basin and the Mediterranean protected it from deep erosion. Increasing Late Miocene shielding of the Sorbas Basin is suggested by strong field evidence for late Messinian uplift of the Sierra Cabrera (study in progress). Another argument for an existing bar- 
rier is the strontium isotope ratios of ostracod shells from the overlying white Lago Mare deposits in the Sorbas Basin. Beets (1992) found that these deviate from those from Lago Mare deposits in central Mediterranean basins. According to the latter author the differences indicate different water masses with increased Sr supply from the Sierta de los Filabres. In the adjoining Vera Basin, in contrast, where evidence for strong local terminal Messinian erosion has been found (Fortuin et al., 1995), the latter authors measured $\mathrm{Sr}$-isotope ratios of ostracod shells similar to those of adjoining Mediterranean basins.

Soon after return of the normal-marine Pliocene sea, the area emerged definitively as a result of overall uplift.

\section{Conclusions}

The special value of the Sorbas sequences lies in the three-dimensionally exposed shoreline architecture. Both extremely well exposed transgressive surfaces and rarely reported, equally well preserved, wave-dominated deepening-up sequences are shown due to lack of burrowing. Together, the sequences permit to estimate amounts of rising and falling sealevel (Fig. 9), although clear time constraints are still lacking.

In sequence-stratigraphic terminology (Van Wagoner and Bertram, 1995) the units can best be classified as parasequences with an upstepping and basinward upstepping pattern of the late highstand. The lower two sequences, which were deposited in a rel- atively large accommodation space created by differential tectonic movements, are simple shallowing-up sequences due to barrier progradation. These can be well compared with classical prograding examples such as from the Cretaceous Western Interior basins of the USA (Van Wagoner and Bertram, 1995).

In the field sequence III also is readily recognized as a parasequence. Upon closer inspection, however, it appears to consist of juxtaposed transgressive and prograding parts, separated by erosional surfaces and flooding surfaces due to sea-level fluctuations within a limited accommodation space. These sea-level fluctuations were in the order of 10 , and even up to 15 $\mathrm{m}$ (Fig. 9). Minor transgressions induced formation of landward-moving washover-fan systems intercalated in lagoonal muds, which finally were eroded by the barrier. Periods of forced regression caused the seaward stepping of temporary barriers. During this process these may show landward erosion, or seaward progradation dependent of the smaller sea-level fluctuations.

Due to its more complex facies architecture, sequence III might form a nomenclatural problem: is it one parasequence or in fact a composite of four stacked parasequences, i.e. of similar ranking as sequences I and II, given the largest sea-level fluctuations deduced? The internal erosion surfaces may be labelled 'minor sequence boundaries', after usage by Van Wagoner and Bertram (1995), but such a term mainly serves to indicate sequencestratigraphic complexities. In fact, ranking of such composite sequences will remain problematic, un-

\footnotetext{
Fig. 19. Conceptual models of variaticn in stratigraphic architecture in response to various types of relative sea-level changes and associated lateral shift of the shoreline modified after Dabrio and Polo, 1996). Illustrated are six (l-VI) hypothetical eustatic sea-level curves (the sinuous lines in the middle) deduced from these deposits and associated shifts of the coast line that can be reconstructed from the lateral and vertical stacking of the coastal sediments (left). (I) Coasial onlap records a steady rise of sea-level (which, in principle, is considered to be continuous; see thisk heavy line) during a single eustatic oscillation ( $s / l$, s/2, etc. indicate successive positions of sea-level). However, a discontinuous rise may produce the same effect. particularly if scrutiny of sections is not close enough. During this process the shoreline moves landwards and upwards. (II) Discontinuous coastal onlap may reflect a continuous sea-level rise with variable sediment input (thick line at the left), a two-step rise with an intervening interruption, or sudden jump upwards (line in the centre), or (even) an intervening minor fall (line at the right). In the meantime, the shoreline progresses as in the former case. (III) Coastal offlap records (quasi) steady sect-level. Seaward shift of shoreline may (or may not) be preceded by other shifts (dotted line with question mark). (IV) A complex coastal offlap with three prograding beach units $(B-1, B-2, B-3)$ at different topographic elevations, each composed of minor prograding units $(a, b, c)$, records at least a first sea-level rise followed by eustatic oscillations reaching progressively lower elevations. The shoreline follows a zigzagging pattem. (V) Two beach units ( $B-l$ older than $B$-2), each with minor offlapping units $(a, b, c)$ record at least two sea-level maxima reaching progressively higher elevations, with an intervening stillstand, or minor fall that complete these oscillations. The shorel ine follows a zigzagging pattem. (VI) A combination of former cases may produce much more complex stratigraphical architectures, such as in the discontinuous coastal onlap plus simple offlap.
} 
GEOMETRY

(ARCHITECTURE)
EUSTATIC $\quad$ SHIFT OF

OSCILLATION COASTLINE

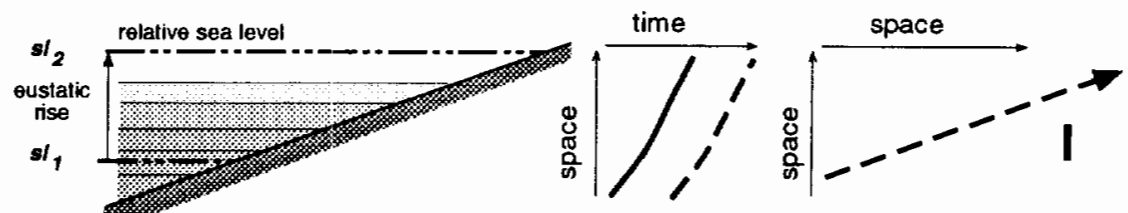

COASTAL ONLAP (SIMPLE)

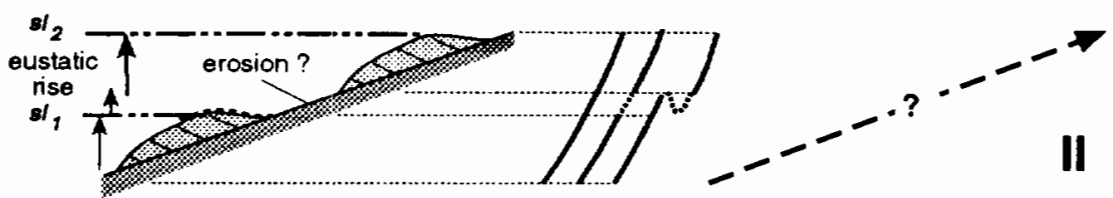

DISCONTINUOUS COASTAL ONLAP

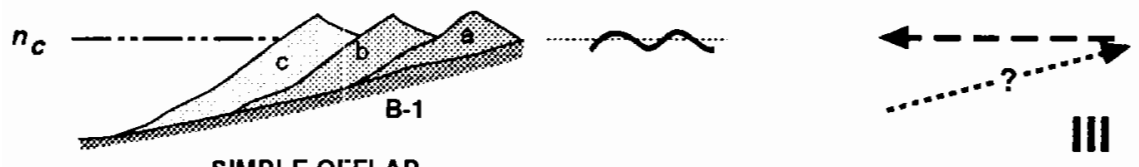

SIMPLE OFFLAP
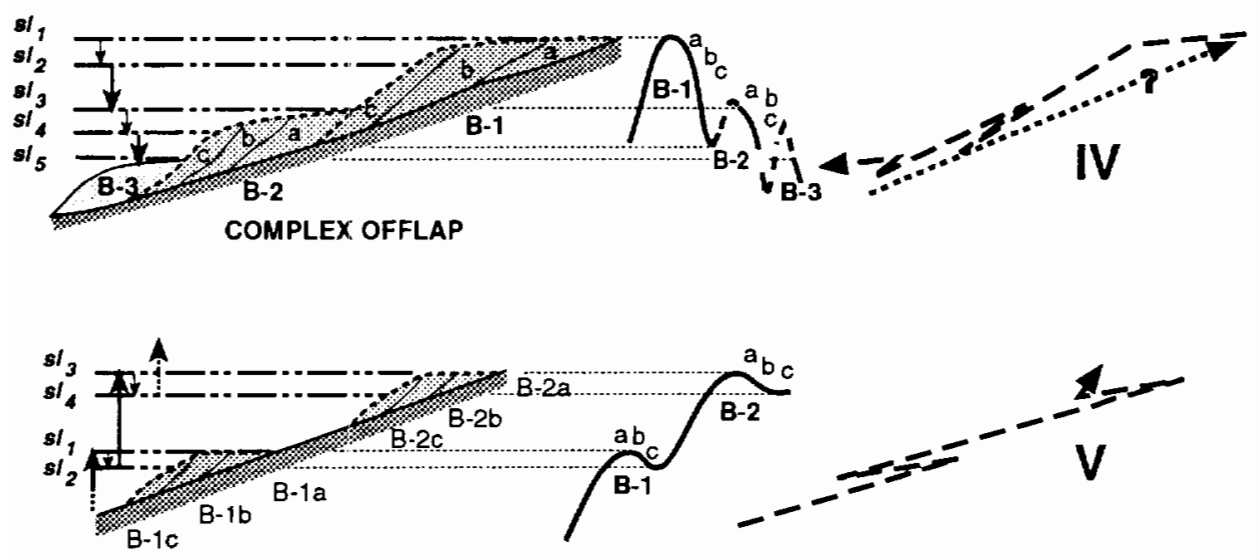

DISCONTINUOUS COASTAL ONLAP + OFFLAP

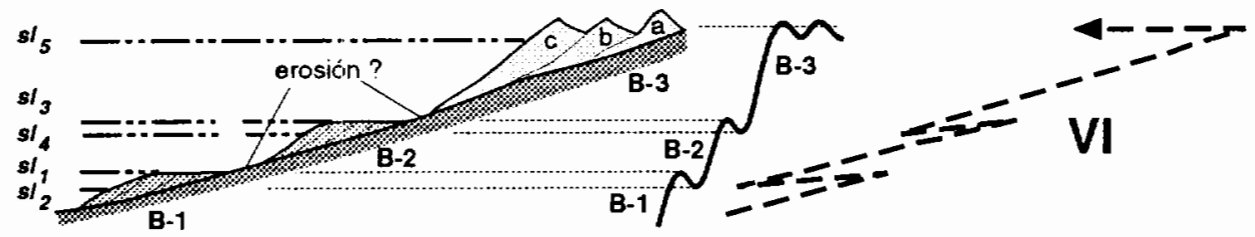

DISCONTINUOUS COASTAL ONLAP + SIMPLE OFFLAP 
til the approximate duration of the various orders of sea-level excursions is knowr and similar order patterns can be compared. This aspect may hamper cyclostratigraphic studies involving the distinction of orbitally forced (Milankovitch) cycles in this type of environment, but in the case of the Sorbas sequences (of which their relation with precession cyclicity is under study) the latter problem could be solved. As pointed out in Section 10, parasequence III of the basin centre can be well correlated with unit 3 of Dabrio and Polo (1995) of the northern basin margin. There the subcycles clearly reflect a lower order of magnitude while unit 3 is of similar size as the two underlying ones. Thus parasequence III indeed may be assumed to have the same ranking as parasequences I and II. Giver the clear evidence that the three Sorbas sequences w'ere deposited under various orders of relative sea-level fluctuations it is concluded that the factor accomrnodation space is of crucial importance to be able tc readily distinguish between the effects of larger and smaller sea-level fluctuations. In other words, with limited accommodation space erroneous sequential (stratigraphic) interpretations are easily made.

The lateral jumping and erosional surfaces in parasequence III seem to be good indicators for a much more reduced accommodation space, as is the exaggerated influence of waves in the foreshore as destructive agents. Minor transgressions lead to formation of a landward-moving washover-fan system intercalated in lagoonal muds and finally become eroded by the barrier. Periods of forced regression lead to seaward-stepping tempcrary barriers, which may move landward in the way just described or prograde seawards dependent of smaller sea-level fluctuations. Two models are given of washover formation, respectively during more rapid and more slow sea-level rise (Figs. 7 and 13). Transgressions in the non-tidal Sorbas setting lead to deposition of washover fans in lagoonal mud with only minor piercing of the barrier, instead of other more common systems with large tidal channels. This aspect restricts sandstone connectivity, so important in hydrocarbon exploration. On the other hand, forced regression with 'stranded' erosive barriers will enhance the sand connectivity.

Six conceptual models have been added (Fig. 19) to illustrate variations in stratigraphic architecture in response to various types of relative sea-level change and associated lateral shift of the shoreline. Situations I, II and III and their combination in example VI all can be found in sequence II, whereas examples IV and $V$ can be found in sequence III. Differentiation in the field between situations IV and $\mathrm{V}$ may be difficult when the boundaries are incompletely exposed. Furthermore, the lateral and vertical relationships are much more complicated due to the interplay of various orders of magnitude of sea-level changes.

The largest downdrop of Mediterranean sea-level occurred after the deposition of the three Sorbas sequences. An overall lack of intensive erosion, except for local channels scoured in the topmost sequence, is seen as an indication that the area then was protected from major channel entrenchment, such as reported from nearby offshore areas and from many other Mediterranean basins.

\section{Acknowledgements}

Various topics were discussed with quite some colleagues, of whom we mention Dirk Beets, Wolfgang Schlager, Tiny Geel, Henk van de Poel, Jeroen Kenter, Francisco Sierro, Cees Biermann, Gerco Stapel, Wout Krijgsman and J.L. Hernandez Enrile. We acknowledge the constructive criticism of the reviewers Franco Ricci-Lucchi and Tom Aigner. The Dutch authors wish to thank the former students Johan ten Veen, Jelger Kooistra and Natasja Vugts for their unflagging enthusiasm during their fieldwork periods in various parts of the Sorbas Basin. CID and MDP received financial support from Project EU EV5V-CT94-0445. TBR acknowledges sponsoring by the Industrial Associates Fund (Prof. W. Schlager). This is contribution Nr. 970140 of the Netherlands Research School of Sedimentary Geology (NSG).

\section{References}

Bardaji, T., Dabrio, C.J., Goy. J.L., Somoza. L., Zazo, C., 1990. Pleistocene fan deltas in southeastern Iberian Peninsula: sedimentary controls and sea-level changes. In: Collella. A., Prior. D.B. (Eds.), Coarse Grained Deltas. Int. Assoc. Sedimentol. Spec. Publ. 10, 129-151.

Beets. C.J., 1992. Calibration of Late Cenozoic Marine Strontium Isotope Variations and its Chronostratigraphic and Geo- 
chemical Applications. Ph.D. Thesis, Vrije Universiteit Amsterdam, Febo, Enschede, 133 pp.

Biermann, C.. 1995. The Betic Cordilleras (SE Spain). Anatomy of a dualistic collision-type orogenic belt. Geol. Mijnbouw 74, 167-182.

Boorsma. L.J., 1993. Syntectonic Sedimentation in a Neogene Strike-Slip Basin (Serrata Area, SE Spain). Ph.D. Thesis, Vrije Universiteit Amsterdam, Febo, Ensichede, 85 pp.

Cita, M.B., Santambrogio, S.. Melillo, B., Rogate, F., 1990. Messinian paleoenvironments: new evidence from the Tyrrhenian Sea (ODP Leg 107). Proc. ODP, Sci. Results 107, $211-$ 227.

Clauzon, G., Suc, J.P., Gautier, F., Berger, A.. Loutre, M.F., 1996. Alternate interpretation of the Messinian salinity crisis: controversy resolved?. Geology 24, 363-366.

Clifton, H.E.. Hunter, R.E., Phillips, R.W., 1971. Depositional structures and processes in the non-barred high-energy nearshore. J. Sediment. Petrol. 41, 651-670.

Dabrio, C.J., 1982. Sedimentary structures generated on the foreshore by migrating ridge and runnel systems in microtidal and mesotidal coasts, S Spain. Sediment. Geol. 32, 14l-151.

Dabrio, C.J., Polo, M.D., 1995. Oscilaciones eustáticas de alta frecuencia en el Neógeno superior de Sorbas (Almería, sureste de España). Geogaceta 18, 75-78.

Dabrio, C.J., Polo, M.D., 1996. Cambios eustáticos y arquitectura estratigráfica de unidades costeras. Geogaceta 20 (2), 438-441.

Dabrio, C.J., Esteban, M., Martín, J.M., 1981. The coral reef of Níjar, Messinian (Uppermost Miocene). Almeria province. S.E. Spain. J. Sediment. Petrol. 51, 521-539.

Dabrio, C.J., Goy, J.L., Zazo, C.. 1985a. A model of conglomeratic beaches in tectonically active areas (Late Pleistoceneactual, Almería, Spain). Proc. 6th Eur. Reg. Meet., I.A.S., Lleida, pp. 104-107.

Dabrio, C.J., Martín, J.M., Megías, A.G., 1985b. The tectosedimentary evolution of Mio-Pliocene reefs in the Province of Almería. In: Milá, M.D., Rosell, J. (Eds.), 6th European Regional Meeting of Sedimentologists, Excursion Guidebook. Lleida, pp. 269-305.

Dabrio, C.J., Roep, T.B., Polo, M.D.. Fortuin, A.R., 1996. Late Messinian coastal barriers and washover fan sedimentation in Sorbas (SE Spain). Geogaceta 21, 205-208.

Davis, R.A.J.R., Fox, W.T., Hayes, M.O., Eoothroyd, J.C., 1972. Comparison of ridge and runnel systems in tidal and non-tidal environments. J. Sediment. Petrol. 42, 413-421.

Dronkert, H., 1977. The evaporites of the Sorbas basin. Rev. Inst. Inv. Geol. Dip. Provincial Univ. Barcelona 32, 55-76.

Dronkert, H., 1985. Evaporite models and sedimentology of Messinian and Recent evaporites. GUA Papers of Geology. Amsterdam, Ser. 1, 24, 283 pp.

Dronkert. H., Pagnier, H., 1977. Introduction to the MioPliocene of the Sorbas basin. In: Field Trip Guide Book, Messinian Seminar III, Trip 2. Malaga-Granada, 21 pp.

Esteban, M., 1979. Significance of the Upper Miocene coral reefs of the western Mediterranean. Palaeogeogr., Palaeoclimatol., Palaeoecol. 29, 169-188.

Esteban, M., Giner. J., 1977. El arrecife de Santa Pola. In: Salas,
R. (Ed.), Primer Seminario Práctico de Asociaciones Arrecifales y Evaporíticas, Barcelona. Unjversidad de Barcelona, Barcelona. p. 11S.

Fortuin, A.R., Kelling. J.M.D., Roep, Th.B., 1995. The enigmatic Messinian-Pliocene section of Cuevas del Almanzora (Vera Basin, SE Spain) revisited - erosional features and strontium isotope ages. Sediment. Geol. 97, 177-201.

Gautier, F.. Clauzon. G., Suc, J.P., Cravatte, J., Violanti, D., 1994. Age et durée de la crise de salinité messinienne. C.R. Acad. Sci. Paris II 318, 1103-1109.

Goldstein. R.H., Franseen, E.K., 1995. Pinning points: a method providing quantitative constraints on relative sea-level history. Sediment. GeoI. 95, 1-10.

Hilgen, F.J., Krijgsman, W., Langereis, C.G., Lourens, L.J., Santarelli, A., Zachariasse, W.J., 1995. Extending the astronomical (polarity) timescale into the Miocene. Earth Planet. Sci. Lett. 136, 495-510.

Hsü, K.J., Ryan, W.F.B., Cita, M.B., 1973. Late Miocene desiccation of the Mediterranean. Nature 242, 240-244.

Hsü, K.J., Montadert, L., Bemouilii. D., Cita, M.B., Erickson, A., Garrison, R.E., Kidd, R.B.. Méllierés, F., Müller, C., Wright, R., 1977. History of the Mediterranean salinity crisis. Nature 267, 399-403.

Krijgsman, W., Langereis, C.G., Santarelli, A., Zachariasse, W.J., 1995. Late Miocene magnetostratigraphy, biostratigraphy and cyclostratigraphy in the Mediterranean. Earth Planet. Sci. Lett. $136,475-494$.

Lickorish. W.H., Butler, R.W.H., 1996. Fold amplification and parasequence stacking patterns in syntectonic shoreface carbonates. Geol. Soc. Am. Bull. 108, 966-977

Martín, J.M., Braga, J.C., 1994. Messinian events in the Sorbas Basin in southeast Spain and their implications in the recent history of the Mediterranean. Sediment. Geol. 90, 257-268.

Martín, J.M., Braga, J.C., 1996. Tectonic signals in the Messinian stratigraphy of the Sorbas basin (Almería, SE Spain). In: Friend, P.F., Dabrio, C.J. (Eds.), Tertiary Basins of Spain, the Stratigraphic Record of Crustal Kinenatics. World and Regional Geology 6. Cambridge University Press, pp. 387391 .

Martín, J.M., Braga, J.C., Riding, R., 1993. Siliciclastic stromatolites and thrombolites, late Miocene, S.E. Spain. J. Sediment. Petrol. 63. 131-139.

Mather, A.E., Westhead, K.E., 1993. Plio/Quaternary strain of the Sorbas Basin, SE Spain: evidence from sediment deformation structures. Quat. Proc. 3, 57-65.

Miller, R.L.. Ziegler, J.M., 1968. A model relating dynamics and sediment pattern in equilibrium in the region of shoaling waves, breaker zone, and foreshore. J. Geol. 66, 417-441.

Montenat, C., Ott d'Estevou, P.. 1996. Late Neogene basins evolving in the Eastern Betic transcurrent fault zone: an illustrated review. In: Friend, P.F., Dabrio. C.J. (Eds.), Tertiary Basins of Spain, the Stratigraphic Record of Crustal Kinematics. World and Regional Geology 6, Cambridge University Press, pp. 372-386.

Montenat, C., Ott d'Estevou, P., de Larouzière, F.D., Bedu, P., 1987. Originalité géodynamique des bassins Néogènes du 
domaine Bétique oriental (Espagne). Notes Mém. CFP, Paris $21,11-50$.

Mutti, E.. Sonnino, M., 1981. Compensation cycles: a diagnostic feature of turbidite sandstone lobes. Abstract Volume, 2nd European Regional Meeting of Interrational Association of Sedimentologists, Bologna, pp. 120-1 2,3 .

Ott d'Estevou, P., 1980. Evolution dynamique du bassin néogène de Sorbas (Cordillères bétiques orien:ales, Espagne). Thèse, Doc. Trav. IGAL, Paris, 1, 264 pp.

Posamentier. H.W., Allen, G.P., 1993. Variability of sequence stratigraphic models: effects of local basin factors. Sediment. Geol. 86, 91-109.

Roep, Th.B., Beets, D.J., 1977. An excursion to coastal and fluvial sediments of Messinian-Pliocene age (Sorbas member and Zorreras member) in the Sorbas basin, S.E. Spain. In: Messinian Seminar 3, Málaga 1977. Fieldtrip Guidebook 2, pp. 22-36.

Roep. Th.B., Van Harten, D., 1979. Sedimentological and ostracodological ohservations on Messiniar post-evaporite deposits in some southeastern Spanish basins. Ann. Geol. Pays Hellén. III $1979,1037-1044$

Roep, Th.B., Beets, D.J., Dronkert, H., Pagnier, H., 1979. A prograding coastal sequence of wave-built structures of Messinian age, Sorbas, Almería, Spain. Sedimen1. Geol. 22, 135-163.

Rouchy, J.M., Saint Martin, J.P., 1992. Late Miocene events in the Mediterranean as recorded by carbonate-evaporite relations. Geology 20, 629-632.

Ruegg, G.J.H., 1964. Geologische onderzockingen in het Bekken van Sorbas, SE Spanje. Unpubl. report, Geol. Inst. University Amsterdam, $64 \mathrm{pp}$.

Short. A.D., Wright, L.D., 1983. Physical variability of sandy beaches. In: Sandy Beaches as Ecosystems. W. Junk Publishers, The Hague, pp. 133-144.

Sierro. F.J.. Flores, J.A., Zamarreno, 1., Vazquez, A., Utrilla, R., Frances, G., Hilgen, F., Krijgsman. W., 1996. Astronomical cyclicity and sapropels in the pre-evaporitic Messinian of the Sorbas Basin (Western Mediterranean). Geogaceta 21, 131134.

Somoza, L., Bardaji, T., Dabrio, C.J., Goy, J.L., Zazo, C., 198687. Análisis de las secuencias de islas barrera pleistocénicas en relación con variaciones del nivel del mar, laguna de La Mata (Alicante). Acta Geol. Hisp. 21--22, 151-157.
Stampfi, G.M., Höcker, C.F.W., 1989. Messinian paleorelief from a 3-D seismic survey in the Tarraco concession area (Spanish Mediterranean Sea). Geol. Mijnbouw 68, 201-210.

Stapel. G.. Moeys, R., Biermann, C., 1996. Neogene evolution of the Sorbas Basin (SE Spain) determined by paleostress analysis. Tectonophysics 255, 291-305.

Tanner. W.F., 1968. High-Froude phenomena. Abstr. Geol. Soc. Am., Annu. Meet.. New Orleans, La., 1967, Program, 220.

Troelstra, S.R., Van de Poel, H.M., Huisman. C.H.A., Geerlings. L.P.A., Dronkert, H.. 1980. Paleoecological changes in the latest Miocene of the Sorbas basin. SE Spain. Géol. Méditerran. 7. $115-126$.

Vail, P.R., Mitchum, R.M., Thompson, S., III, 1977. Seismic stratigraphy and global changes of sea level, 3. Relative changes of sea level from coastal onlap. In: Payton, C.E. (Ed.), Seismic Stratigraphy Applications to Hydrocarbon Exploration. Am. Assoc. Pet. Geol. Mem. 26, 63-82.

Van de Poel, H.M., 1994. Messinian marginal-marine and continental facies and their stratigraphy in the eastern Almeria Province (S.E. Spain). Strata. Actes du Lab. de Géologie Sédiment. et Paléontol. de l'Université Paul Sabatier, Toulouse. Sér. 2, Mém. 23, $202 \mathrm{pp}$.

Van Wagoner, J.C., Bertram, G.T. (Eds.), 1995. Sequence Stratigraphy of Foreland Basin Deposits. Am. Assoc. Pet. Geol., Mem. 64, 487 pp.

Völk, H.R., 1967. Zur Geologie und Stratigraphie des Neogenbeckens von Vera. Südost Spanien. Ph.D. Thesis, Lniv. of Amsterdam, 160 pp.

Völk, H.R.. Rondeel, H.E., 1964. Zur Gliederung des Jungtertiärs im Becken von Vera, Südostspanien. Geol. Mijnbouw 43 , $310-315$

Weijermars, R., Roep, Th.B., Van Den Eeckhout, B., Postma, G., Kleverlaan, K., 1985. Uplift history of a Betic fold nappe inferred from Neogene-Quaternary sedimentation and tectonics (in the Sierra Alhamilla and Almeria, Sorbas and Tabernas Basins of the Betic Cordilleras, SE Spain). Geol. Mijnbouw 64, 379-411.

Zazo, C., Goy, J.L., Somoza, L., Dabrio, C.J.. Belluomini, G., Improta, S., Lario, J., Bardaji, T., Silva, P.G., 1994. Holocene sequence of sea-level fluctuations in relation to climatic trends in the Atlantic-Mediterranean Linkage Coast. J. Coastal Res. $10,933-945$. 